REX-J ミッションにおける画像処理を用いたテザ一移動の評価

\author{
鈴木 悟史 ${ }^{* 1}$, 吉井 正広 ${ }^{* 2}$, 中西 洋喜*3, 山隅 允裕 ${ }^{* 4}$, 小田 光茂 ${ }^{* 3}$
} 上田 敦史 ${ }^{* 5}$, 渡邊 恵佑 ${ }^{* 5}$ ，加藤 裕基 ${ }^{* 5}$ ，星 亜友美 ${ }^{* 5}$ ，西田 信一郎 ${ }^{* 6}$

\title{
Evaluation of the tether based locomotion using image processing in the REX-J mission
}

\author{
Satoshi SUZUKI ${ }^{* 1}$, Masahiro YOSHII ${ }^{* 2}$, \\ Hiroki NAKANISHI ${ }^{* 3}$, Mitsuhiro YAMAZUMI ${ }^{* 4}$, Mitsushige ODA ${ }^{* 3}$, \\ Atsushi UETA $^{* 5}$, Keisuke WATANABE ${ }^{* 5}$, Hiroki KATO ${ }^{* 5}$, Ayumi HOSHI ${ }^{* 5}$ \\ and Shinichiro NISHIDA ${ }^{* 6}$ \\ ${ }^{*} 1, *_{2}$ Advanced Engineering Services Co.,Ltd. \\ 1-6-1 Takezono, Tsukuba-shi, Ibaraki 305-0032, Japan \\ ${ }^{* 3, * 4}$ Tokyo Institute of Technology \\ 2-12-1 Ookayama, Meguro-ku, Tokyo 152-0033, Japan \\ ${ }^{* 5, * 6}$ Japan Aerospace Exploration Agency \\ 2-1-1 Sengen, Tsukuba-shi, Ibaraki 305-8505, Japan
}

\section{Received 4 June 2014}

\begin{abstract}
Image processing is one of the methods used to measure position/attitude for robot control and there are hopes that it can be applied to space robot missions, including REX-J (Robot EXperiment on ISS/JEM). The REX-J mission involves space robot locomotive function experiments using tethers by JAXA. Measuring the robot's motion accurately is crucial to establishing the new locomotive technology using tethers. With conventional methods, a suitable illumination environment is configured for high-precision image processing and a characteristic marker is attached to the measurement object. However, the two challenges posed for image processing during the REX-J mission are: (1) the illumination of space changes significantly with orbital motion and (2) the robot lacks a characteristic marker. Accordingly, our purpose is to develop a marker less image processing method for the illumination environment of space and measure the robot's position/attitude of the REX-J mission by image processing. The proposed new image processing method involves creating virtual points are created at the intersection of the robot's edge in the image, which are then used as markers for image processing. This method is robust for changes in the illumination environment because it allows the creation of a virtual point, even if the edge is incomplete. The method is applied to the REX-J mission and the measurement accuracy of the robot's position/attitude in the illumination environment of space was confirmed as on the sub-pixel level. Subsequently, the position/attitude of the robot during movement by tethers was measured by image processing. In addition, the error in the robot's position/attitude, as estimated from the length of the tethers, was clarified by the image processing result. Based on these results, the robot's locomotive function by the REX-J mission was verified.
\end{abstract}

Key words : Space robot, Locomotion function, Image processing, Marker less, REX-J

\section{1. 緒言}

REX-J（Robot Experiment on JEM）ミッションは，宇宙飛行士が行う船外活動等を支援するロボット（有人宇宙

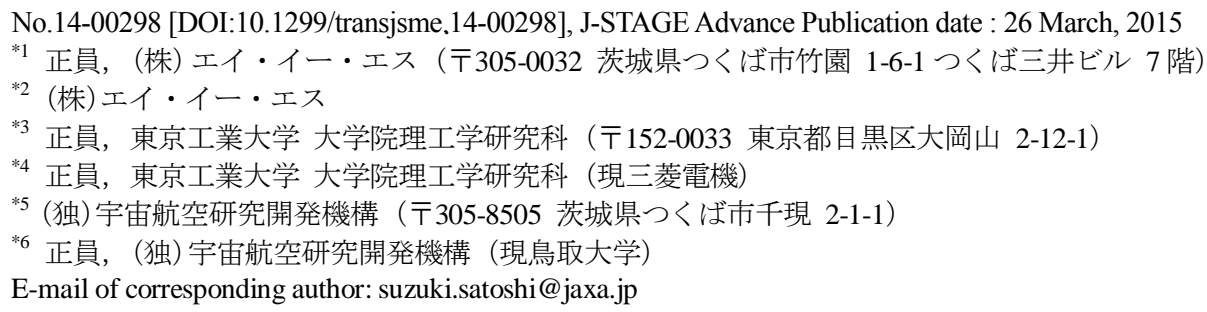

E-mail of corresponding author: suzuki.satoshi@jaxa.jp 
活動支援ロボット）の実証を目的として，国際宇宙ステーション 日本実験棟（きぼう）にて 2012 年 8 月より実 施されたロボットの実験である，REX-J ミッションでは，有人宇宙活動支援ロボットの実現のために不可欠な空 間移動技術に関する実験を実施した。REX-J ミッションで実証する空間移動技術とは，SRA（Storable tubular extendable member Robot Arm）と呼ばれる伸縮可能な伸展式ロボットアームと，テザーと呼ばれるひもを用いた 空間移動(Oda, et al., 2012)であり, 移動に要する機構が小型軽量でありながら広範囲の移動が可能となるメリット を持つ. 図 1 に REX-J ミッションにて実証を目指寸空間移動技術のイメージ(宇宙航空研究開発機構，2011)を示 す、ロボット本体は，テザーとその長さを制御するためのリール，および伸展式ロボットアームが搭載されてい る. テザーの先端には，テザーを係留するためのフックが取り付けられている. このフックを，宇宙飛行士が移 動の際に使用するハンドレールと呼ばれる手すりに取り付けることで， ロボット本体が移動可能となる領域を拡 大寸ることができる. フックの操作には, 伸展式ロボットアームを使用する. 伸展式ロボットアームは, 先端に 手首機構およびハンドを備えており,ハンドレールに対してフックの脱着を行う機能を持つ.この機能によって, ロボット自身がフックの係留先を変更することができる.

このようなテザーを用いる空間移動技術を実証することは，小型軽量でありながら広範囲の移動が可能なロボ ットの実現に向けて必要であり, 有人宇宙活動支援ロボットの実用化のためには不可欠である. REX-J ミッショ ンでは，空間移動技術の実証のため，伸展式ロボットアームによるフックの係留，およびテザー制御による移動 を宇宙の曝露環境で実証した.
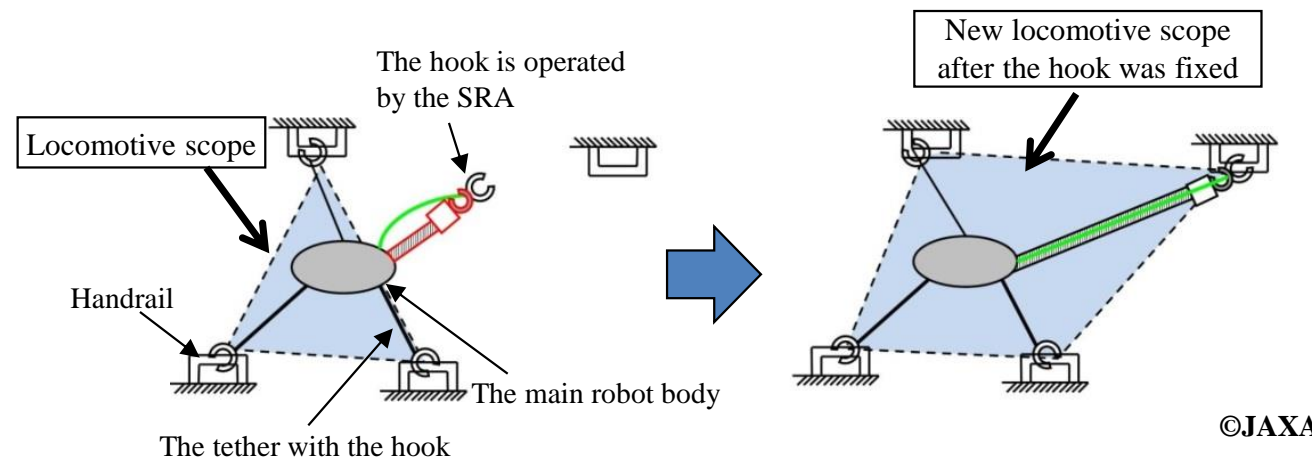

Fig. 1 Locomotion technology demonstrated in the REX-J mission. The robot has a tether and an extendable arm, named SRA, while a hook is attached to the tip of the tether and operated by the SRA. The hook, in turn, is attached to a handrail. The robot gained new locomotive scope after the hook was fixed.

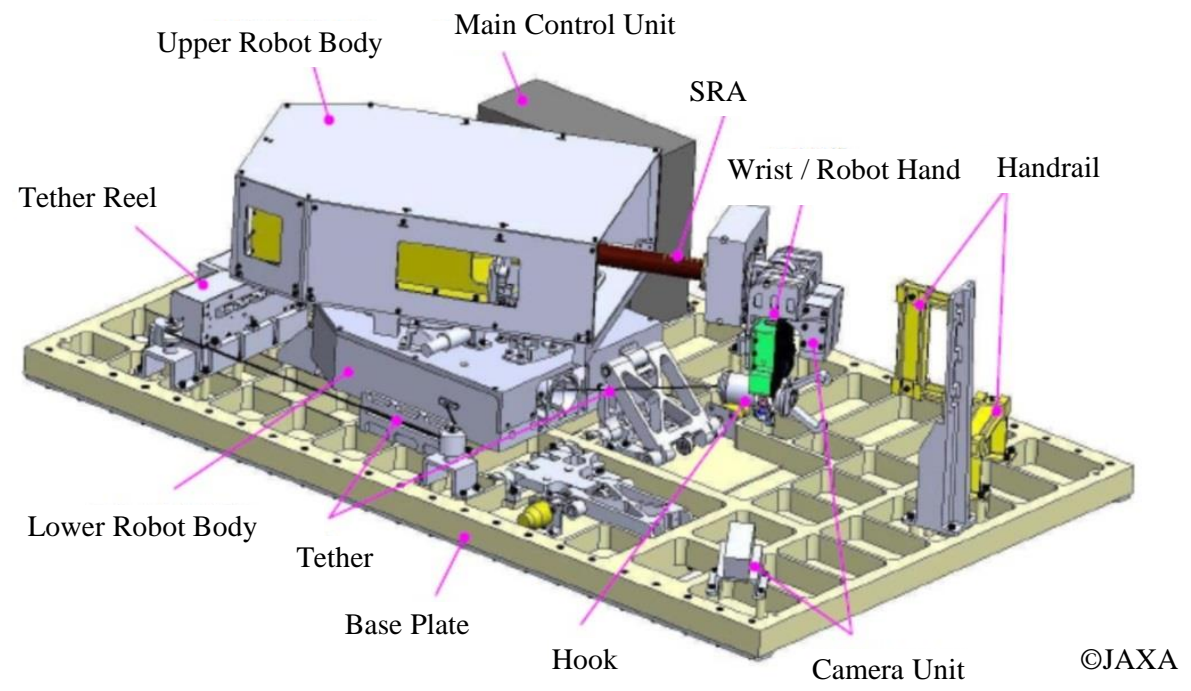

Fig. 2a This experimental device was used in the REX-J mission. The robot's body comprises the upper and lower body, the latter of which has three tethers, while the robot upper body has SRA, a wrist and a robot hand. The robot is hung in three tethers and gains two-dimensional locomotive scope after the hook is fixed by SRA. 
Suzuki, Yoshii, Nakanishi, Yamazumi, Oda, Ueta, Watanabe, Kato, Hoshi and Nishida, Transactions of the JSME (in Japanese), Vol.81, No.824 (2015)

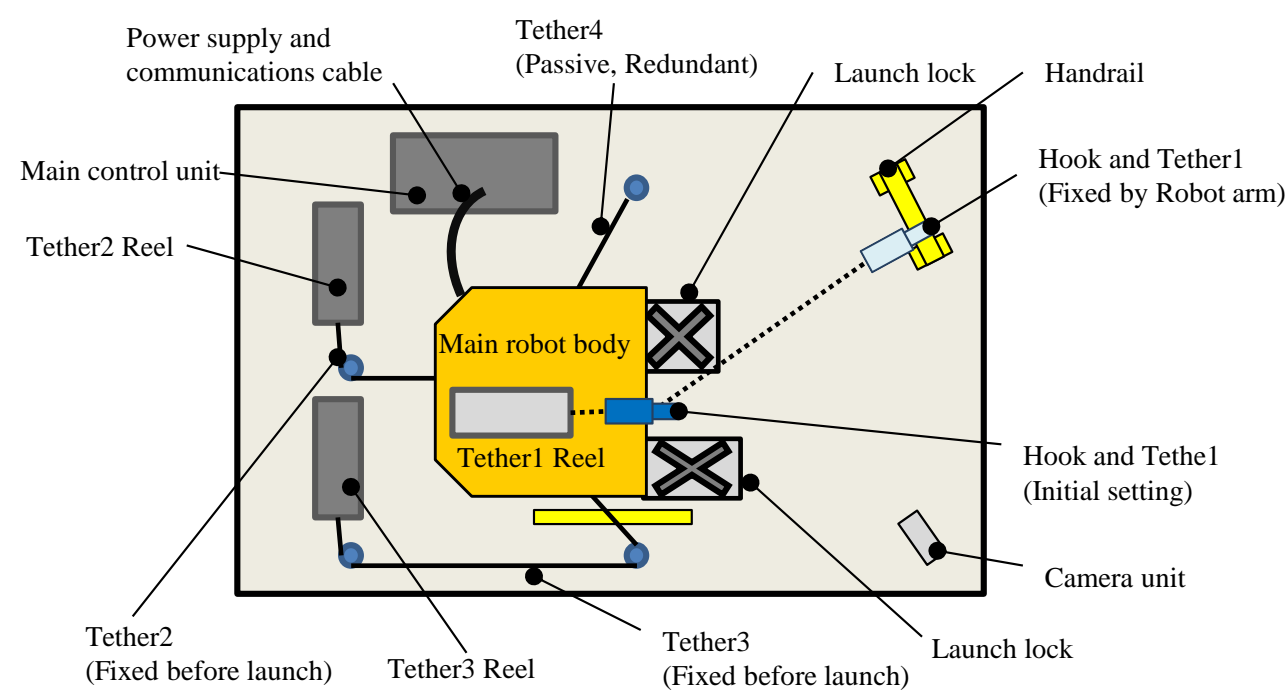

Fig. 2b The REX-J mission robot has three active tethers and one passive tether. Two active tethers are fixed before launch and the other is fixed to the handrail by a robot arm after the launch. The passive tether is fixed for redundancy and was thus not used in the experiment involving locomotive function.

図 2a に REX-J ミッションにおける実験装置の外観(宇宙航空研究開発機構，2011)を，図 2b にテザー移動実験 に係る搭載機器の配置を示寸．ベースプレート上に搭載されたロボット本体は，2 段式となっている．ロボット 本体下段は，長さ制御可能な 3 本のテザーと固定長である 1 本のテザーを持つ. 長さ制御可能な 3 本のテザーの 内 2 本は，テザー 2 およびテザー 3 と呼ばれ，ロボット本体外に設置されたリール機構で制御される. テザー 2 と テザー3 は，打ち上げ時点で既にロボットに取り付けられており，テザー係留済みの状態を模擬している．長さ 制御可能なテザーの残る 1 本は, テザー 1 と呼ばれ，打ち上げ時点では未係留であり，ロボット本体内部のリー ル機構によって巻き取られた状態となっている．テザー1 の先端にはフックが取り付けられており，ロボット本 体上段に搭載された伸展式ロボットアームによって，ロボット自身がフックをハンドレールへと係留する．フッ クの係留が完了すると， ロボット本体は長さ制御が可能な 3 本のテザーによって懸垂された状態となり，それぞ れのテザー長を変えることで平面内を移動することができる.

また, テザー4 は, テザー 1 が取り付けられない状態となった際に使用される予定のテザーである. テザー4は, テザー1にトラブルが発生した際にも移動実験を継続するための冗長系であることから，テザー長を制御するた めのリール機構は持たず，固定長である. 本論文におけるテザ一移動実験では, テザー4 は常にたるむ方向に口 ボットが移動する実験を行なっていることから，テザー4の影響は考慮しない.

有人宇宙活動支援ロボットの実用化に向けて, 宇宙環境においてテザーで懸垂された状態のロボット本体の移 動時の挙動を把握することは重要な課題である.しかし，REX-Jのように船外の曝露環境下においてテザーで懸 垂されたロボット本体の挙動が詳細に評価された例は無く, REX-J ミッションによって得られたデータを基にテ ザー移動機能を評価することは非常に重要である.

REX-J ミッションでは, ロボット本体の位置・姿勢は, テザー長のテレメトリデータから推定される(山隅他, 2013). ただし, 推定によって得られたロボット本体の位置・姿勢は, テザーの伸びや繰り出し長の誤差, フック によって係留したテザー位置の誤差等の影響を受けることが懸念されている.

よって, テレメトリによるテザー繰り出し長の情報以外から，ロボット本体の位置・姿勢を計測する方法が求 められており，REX-J ミッションにおける実験モニタ用のカメラで撮影された画像を用いた画像処理による計測 が有力な候補の一つとされている.

カメラをセンサとして使用する画像処理技術は, 近年多くのアプリケーションに適用されるようになっている. ただし，画像処理を用いて高精度な計測を行う場合，計測対象の誤認識防止や位置特定精度の向上のため，対象 の視認性向上が重要な課題となる. 多くの画像処理では, 画像処理用途に特化した光の照射技術(増村, 2002)を 用いることや，計測すべき対象に特徴的なマーカを搭載すること(上村，西田，2005，鈴木他，2013a), そして画 像処理に十分な解像度を持つカメラを選定すること等の方法により, 高精度の画像処理を実現している. 
これに対し, 軌道上においては, 照度が $10^{3}$ から $10^{5} \mathrm{~lx}$ オーダで変化し, 軌道運動に伴う日陰も存在する(小田, 稲場，2002)等，画像処理に適した照明環境は期待することができない．また，既に軌道上で運用が開始されてい る衛星や軌道上に存在するデブリは，ロボットによる捕獲や修理が前提とされていないため，画像処理のための マーカが搭載されていないことが多い。このため,今後必要になると考えられるデブリの捕獲ミッションでは, マ 一カを基にデブリの位置・姿勢を計測することは期待できない. さらに, 通信上の制限から十分な解像度の画像 を得ることができない場合も十分想定される．REX-J ミッションにおけるロボット本体も画像処理用のマーカは 搭載されておらず，通信上の制限から画像処理のために適した解像度の画像を得ることも難しい，よって，低解 像度の画像を用いたマーカレスでの画像処理手法が必要となる.

マーカの無い非協力のターゲットに対し，画像を用いて位置・姿勢計測を行う手法は，宇宙空間におけるデブ リ捕獲技術のための位置・姿勢計測でも検討されている(久保田他，2012). ただし，これは，画像中から比較的 抽出しや寸いと考えられる円形の領域を利用寸るものであり, REX-Jミッションにおけるロボット本体の画像処 理に対しては, 適用が難しいと考えられる.このため, マーカの無い複雑形状のターゲットに対し, 画像から位 置・姿勢の計測を行う技術の開発が望まれる.そこで，ターゲットの持つエッジの交点を仮想的なマーカ点とし て位置・姿勢を計測する画像処理手法を新規に提案し, REX-Jミッションにおけるロボット本体の位置・姿勢計 測に適用することで評価を行なった。

本報告では, REX-J ミッションにおけるロボット本体の位置·姿勢計測のための画像処理手法について説明し, これを用いた計測結果を基に, テザー長からロボット本体の位置・姿勢を推定する手法を評価した結果について 述べる.

\section{2. 画像を用いたロボット本体位置・姿勢計測のための前提条件}

\section{$2 \cdot 1$ カメラ}

図 3 に示すように, REX-J ミッションの実験装置には, CAM (CAMera unit)と呼ばれる 4 台の小型カメラユニッ トが搭載されている. CAM は, 照明装置として LED を備えており, 日陰中であっても実験の様子をモニタする ことができるようになっている. 表 1 に小型カメラユニットの主要諸元(宇宙航空研究開発機構, 2011)を示寸. 4 台の CAM のうち 3 台はロボット本体に搭載され, 主にフックの操作や伸展式ロボットアームの動作特性把握の ために使用される．残る 1 台は，実験の様子をモニタするために実験装置のベースプレート上に搭載されたもの であり, REX-Jミッションにおける実験領域の多くをカバーする視野を持つ. 本研究では, ベースプレート上に 搭載された CAM（以下，CAM4 と呼ぶ）の撮影画像を使用する.

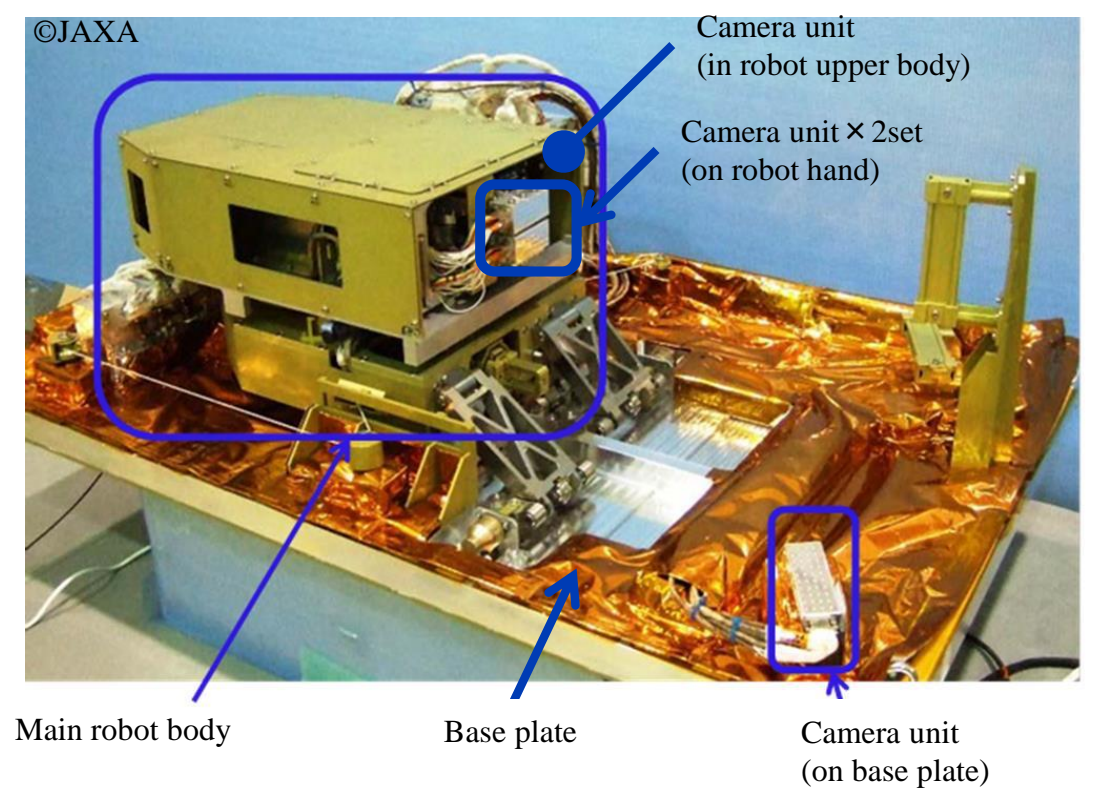

Fig. 3a The experimental device of the REX-J mission has four camera units (CAM). 


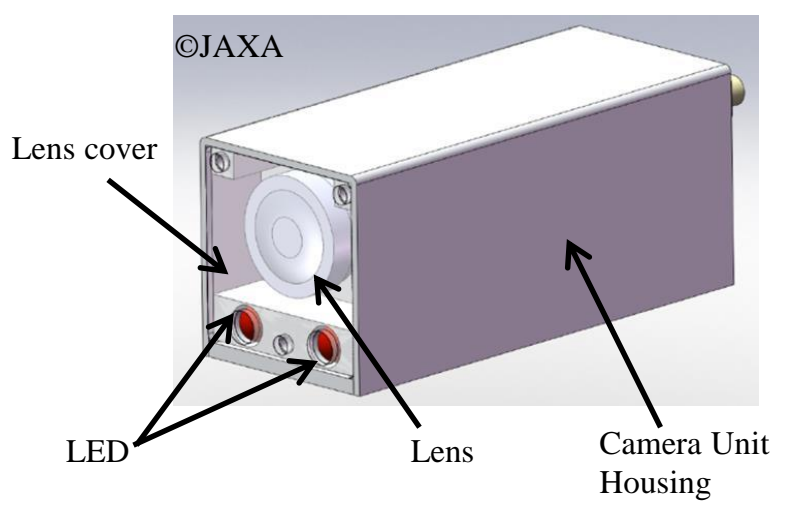

Fig. 3b The CAM has two LED lighting installations.

Table 1 Specifications of CAM

\begin{tabular}{l|l}
\hline \hline \multicolumn{1}{c|}{ Name } & \multicolumn{1}{c}{ Specification } \\
\hline Size & W30mm $\times$ D30mm $\times$ L70mm \\
\hline Mass & $0.3 \mathrm{~kg}$ \\
\hline Resolution & $320 \times 240$ pixels \\
\hline & $\begin{array}{l}\text { Horizontal 78.63deg } \\
\text { Vertical 63.63deg } \\
\text { Angle of view }\end{array}$ \\
\hline Video output & NTSC \\
\hline
\end{tabular}

図 4 にCAM4 によって撮影された画像例を示寸、ロボット本体が移動できる範囲が視野内にあり，テザーによ る移動の様子をモニタすることが可能である．なお，ロボット本体が移動する際の照明環境変化に合わせてリア ルタイムに CAM の撮影条件を指定することは，運用上の制約からできない．このため，シャッター速度やホワ イトバランス等の撮影条件は，CAM におけるイメージャの初期設定であるオート設定を使用している．このオ 一ト設定であっても，実験のモニタ用途として使用することはできるが，大きく変化する照明環境に対応し，常 に同等の品質の画像を得ることはできない(益子他，2013). 特に日陰中の LED 照明環境下では, 全体的に暗く口 ボット本体の一部に影が落ちる等，日照中に撮影された画像と比較して視認性は低下している．視認性の低下に 加え, 画像上のロボット本体の様子が日照と日陰で大きく変化するため, エッジや特徵点を一意に設定しにくく, 画像処理に適した画像が撮影される条件とはいえない.

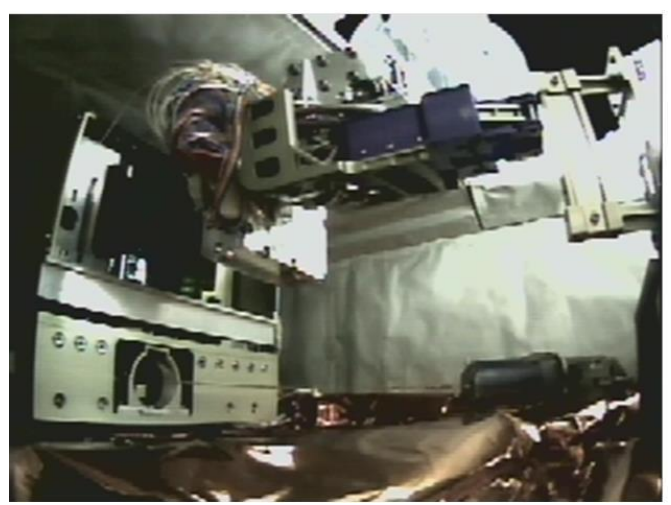

Fig. 4a An example of an image taken by CAM 4. (in sunshine) The edge is relatively clearer than the umbra.

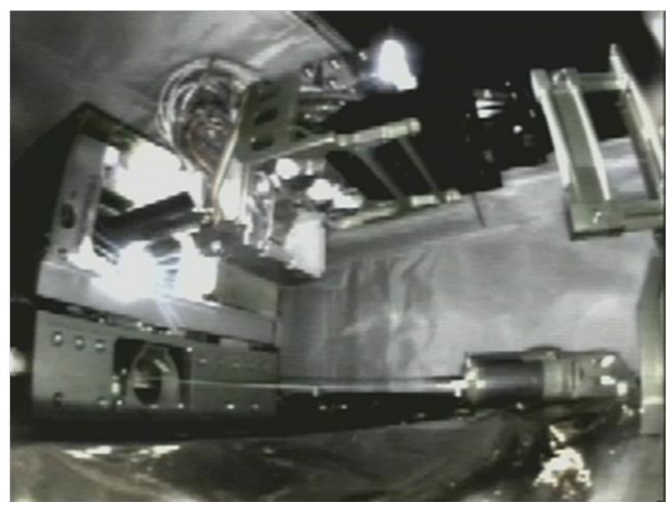

Fig. 4b An example of an image taken by CAM 4. (in umbra) The main robot body is dark, and the edge is unclear. 


\section{$2 \cdot 2$ 座標系}

ロボット本体の位置・姿勢計測に係る座標系を図 5 に示す、ロボット本体の位置・姿勢計測には，原点となる 座標系および, ロボット本体の移動と共に変化するローカルな座標系の定義が必要である. 原点となる座標系は, 実験エリア端点に固定された REX-J ミッションにおけるグローバルな座標系であり，ロボットの位置・姿勢によ って変化しない，これを世界座標系と呼ぶ。一方，ロボット本体の移動と共に変化する座標系は，ロボット本体 下段前面の中央とし，これをロボット座標系と呼ぶ。画像処理では，ロボット本体の位置・姿勢として，世界座 標系に対するロボット座標系の位置・姿勢を計測する.

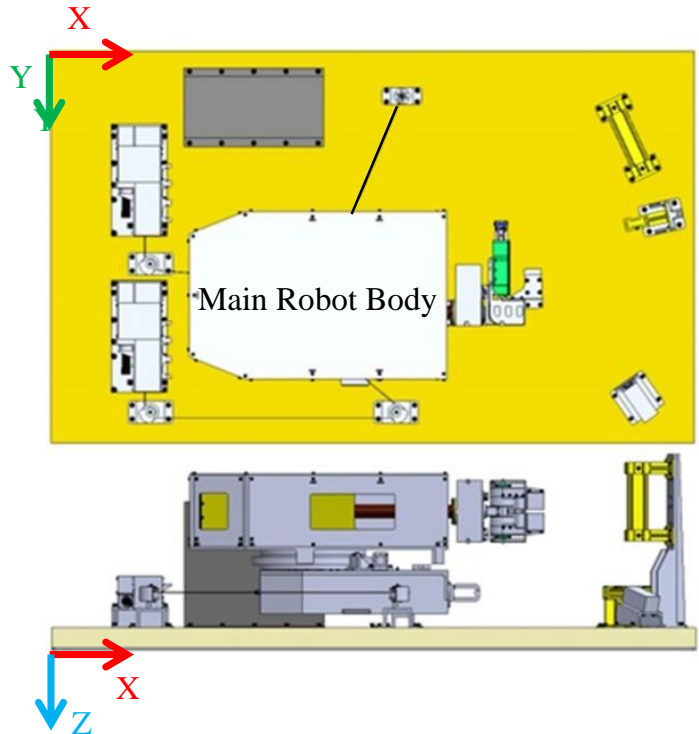

Fig. 5a The origin of the global coordinate system is the corner of experimental area in the REX-J mission.

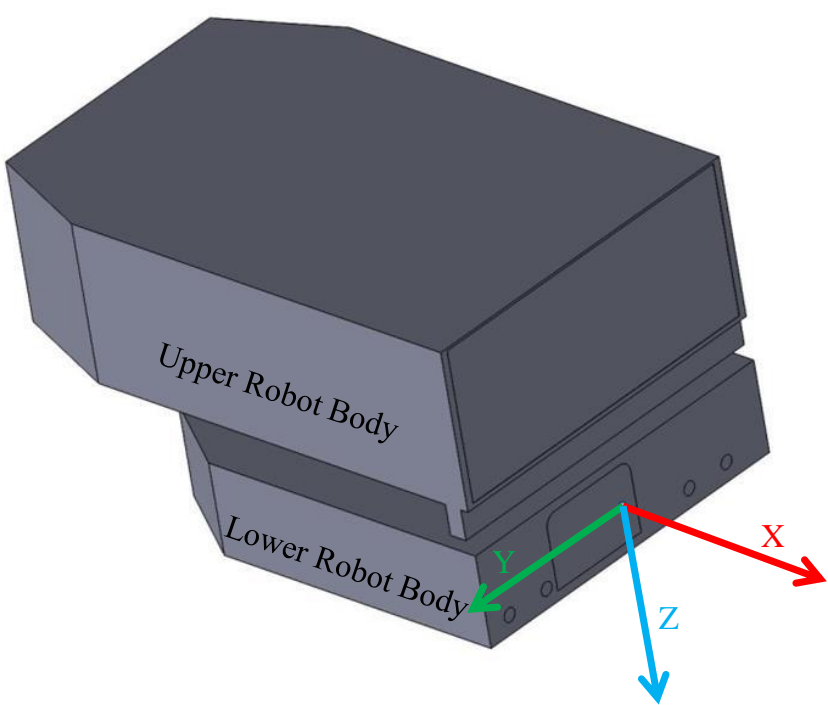

Fig. 5b The origin of the robot coordinate system is the frontal center of the lower robot body. The robot coordinate system moves with the locomotion of the main robot body.

\section{3. ロボット本体位置・姿勢計測のための画像処理手法}

\section{$3 \cdot 1$ 画像処理手法の概要}

ロボット本体位置・姿勢計測のための画像処理では，マーカの無いロボット本体を画像から抽出し，この結果 を基にロボット本体の位置・姿勢を算出寸ることが求められる．提案する画像処理手法は，主に 3 つの工程から 構成される．1つめは，マーカの無いロボット本体への特徵点の設定である．2つめは，画像からの特徵点抽出 である．3つめは，画像から得た特徵点を基にしたロボット本体位置・姿勢の算出である. これらの 3 つの工程 の詳細について，以下に述べる。

\section{$3 \cdot 2$ マーカの無いロボット本体への特徴点の設定}

前述のとおり，ロボット本体には，位置・姿勢計測用のマーカは搭載されていない，よって，マーカの代わり となる特徵点を設定するため，ロボット本体の特徴的な形状を利用することとした．図 6 に，位置・姿勢計測の ために使用する特徵形状を示す，今回用いた特徵形状としては，ロボット座標系における位置が既知であるロボ ット本体前面の直線エッジ，およびロンチロック固定用の穴の円形エッジである. しかし，これらの特徴形状を 抽出する際に問題となるのが，照明環境の変化，およびロボット自身の動きである．これらの影響により，抽出 目標である特徴形状の一部が隠れてしまう場合が存在する．例えば，手首やハンドの動作によってエッジの一部 が隠れてしまう場合や，照明環境変化によってエッジそのものの視認性が大きく低下寸る場合等に特徵形状の追 跡が困難となることが予想される．こうした問題を解決寸るため，直線エッジについては，形状そのものをマー カとするのではなく，直線エッジを延長した交点に仮想的なマーカ(以下，仮想マーカ点と呼ぶ)を設ける方法を 提案する.エッジの交点を仮想的なマーカとする方法であれば，ロボット本体の動きや照明環境の影響によって 
エッジの一部が隠れた場合でも，直線エッジを延長することによって交点を得ることができる．また，仮想マー カ点は，画像上のエッジの交点に対応するロボット座標系の位置情報が既知であれば良いことから，直接交差し ていない直線エッジであっても，それらを延長した結果として交差する場合であれば，仮想マーカ点を設定する ことができる，この結果，画像上は特徵点になりえない部分にも仮想マーカ点を作成できるという利点がある.

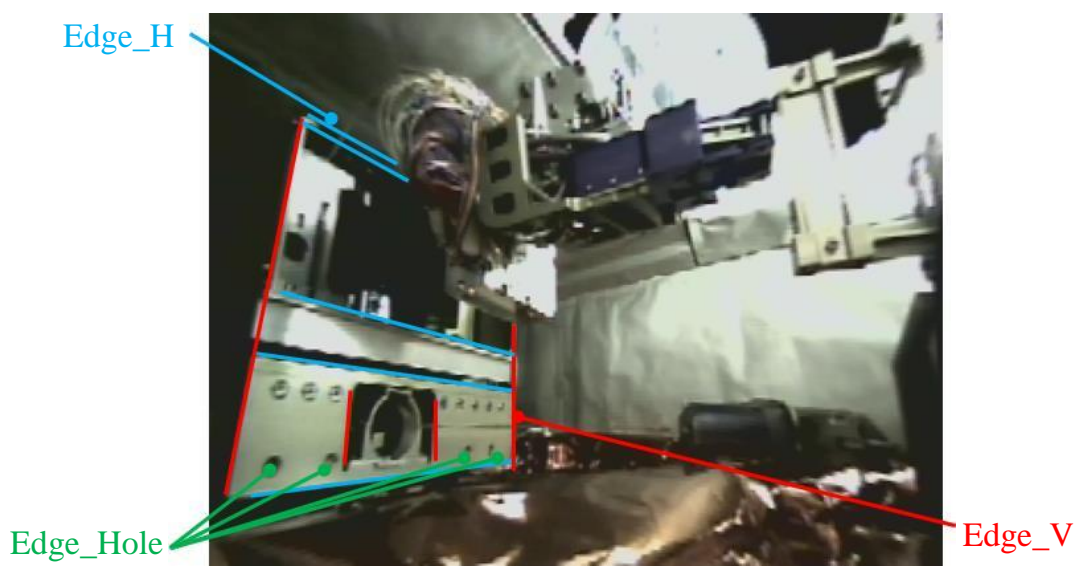

Fig. 6 The characteristic edge is used for image processing. The blue and red lines are the horizontal and vertical edges respectively, while the green point is the circular edge. However, the edge itself is not used as a substitute for the marker. The straight-line edge is extended, its intersecting points are set as markers and designated as virtual marker points. Even if part of the edge is hidden, virtual marker points are detected via image processing.

\section{$3 \cdot 3$ 画像からの特徵点抽出}

仮想マーカ点は，前節で述べた通り，直線エッジの場合には，その交点に設定する．このため，直線のエッジ は，画像上でも直線として表示されることが求められる．しかし，CAMによる撮影画像には，レンズの影響に よる歪みが存在し, 画像の中心から離れた場所では, 図7aに示すように, 実際は直線であるエッジが, 画像上で は円弧のように表示されてしまう。この影響で, エッジを延長して算出した仮想マーカ点の位置は, 歪みの影響 によりずれる可能性がある. このため, 画像処理に先立って, 歪みの補正が必要となる. 歪みを補正するための パラメータは，打ち上げ前にCAM のキャリブレーションによって取得(鈴木他，2013b)したものを使用した．こ の值を用いてレンズの影響による放射歪みを補正した結果を, 図 $7 \mathrm{~b} に$ 示寸. この画像から, 初回フレームのみエ ッジ抽出候補となるエリアを設定する.

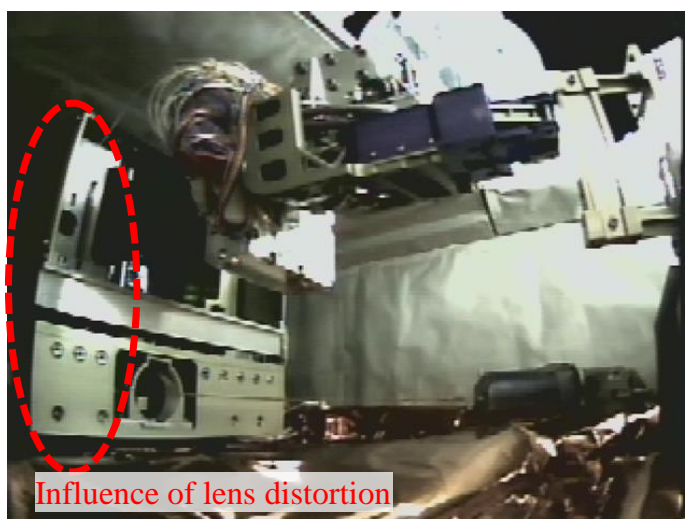

Fig. 7a The edge bends under influence of lens distortion.

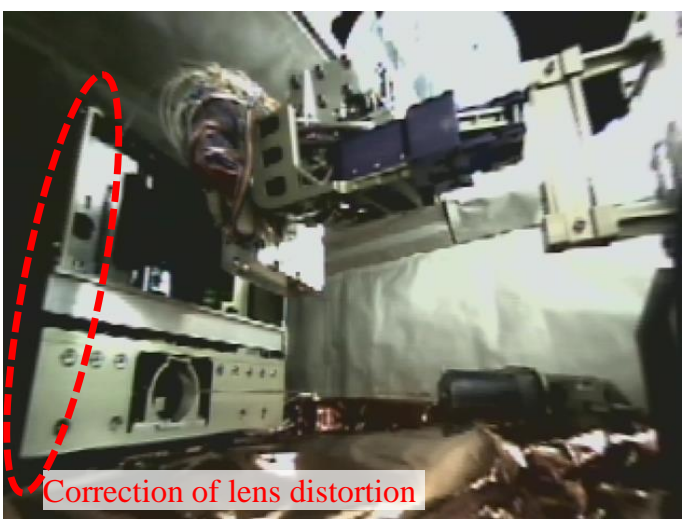

Fig. 7b The impact of lens distortion on the edge is corrected.

特徵点となる仮想マーカ点の抽出は，放射歪み補正後の画像を用いて実施した．仮想マーカ点抽出のためのア ルゴリズム概要を図 8 に示す。仮想マーカ点の抽出のためには, 画像から Canny 法(Canny, 1986)を使用してエッ ジを取得する，得られたエッジはノイズを含むが，画像上のエッジの方向やサイズを基にエッジとノイズの識別 を行なった。こうして得られたエッジが，仮想マーカ点を求めるために使用される. 図 6 の直線エッジである Edge_HおよびEdge_Vについては，得られたエッジを直線近似する. 直線近似には，重み付きの最小二乗ライン 
フィッティングを用いる，最小二乗ラインフィッティングでは，回帰直線を算出し，エッジを構成する各点から 回帰直線までの平均距離を算出する。この平均距離に任意の係数を乗算したものをパラメータとし，各点におけ る回帰直線までの距離がパラメータよりも大きいものは，回帰直線の計算から除外する．これを任意の回数繰り 返すことで直線近似を行う。こうして近似された直線エッジを延長し, 直線エッジ同士の交点を仮想マーカ点と する.

仮想マーカ点の抽出結果を図 9 に示す．赤いラインが画像から得たエッジを直線近似した結果であり，青の十 字がエッジを延長することで算出した仮想マーカ点である. 図 9a は, 日照環境にある時に撮影された画像であり， エッジが比較的取得しやすい条件である。これに対し，図 $9 \mathrm{~b}$ は，日陰環境にある時に撮影された画像であり，ロ ボット本体のエッジが日照時と比較して不明瞭である。しかし，このような不明瞭なエッジを持つ画像であって も，複数の仮想マ一カ点を得ることができている．なお，一度仮想マ一カ点を得た後は，次のフレーム以降は， 前フレームにて抽出したエッジ情報を基に，自動でエッジ抽出のための候補エリアが選定される.



Fig. 8 Algorithm to extract virtual marker points. The virtual marker points extracted from an image are used to calculate the robot position/attitude.

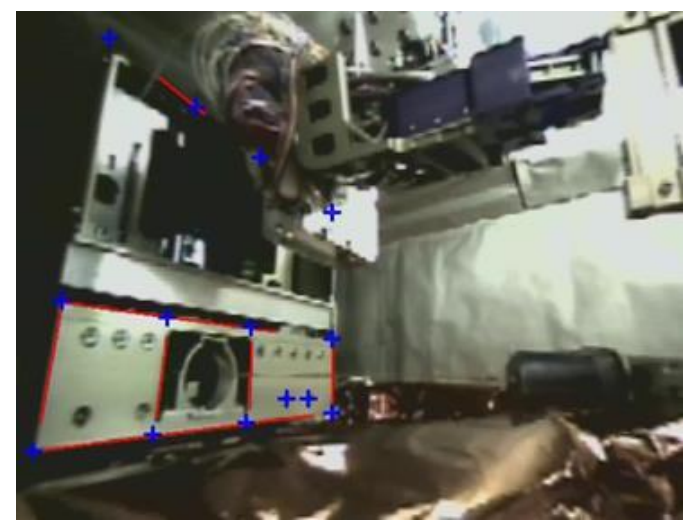

Fig. 9a Red lines are edges extracted by image processing, while blue crosses are virtual marker points. Virtual marker points are prepared into the intersecting point of the edge.

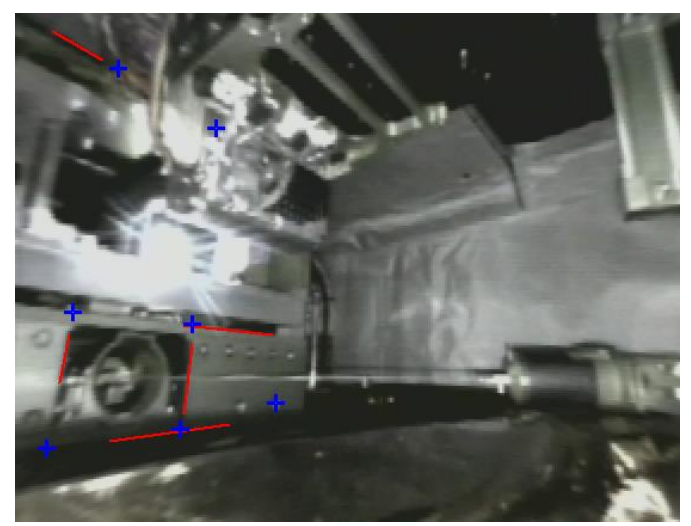

Fig. 9b The image was taken in umbra and is partly unclear, although virtual marker points are obtained. 


\section{$3 \cdot 4$ 画像から得た特徴点を基にしたロボット本体位置・姿勢の算出}

直線エッジの交点より算出した仮想マーカ点が 4 点以上あれば， 3 次元空間内の平面を画像に投影する平面射 影変換行列（Homography）を算出することが可能である. Homography は，キャリブレーションによって得たカ メラの内部パラメータを基にしたカメラ行列と, ロボット座標系における仮想マーカ点位置を画像平面上におけ る仮想マーカ点位置に座標変換する行列を掛け合わせたものである. よって, カメラの内部パラメータが既知で あれば, Homography を算出することによって，カメラに対する計測対象の位置・姿勢の算出が可能である(加藤 他, 1999). また, 仮想マーカ点が 5 点以上ある場合には, 最小二乗法を用いて Homography を算出する(劉, 長谷, 2012).

ただし，精度の良い計測のためには，画像から得られる仮想マーカ点の画像上の位置誤差は小さい方が望まし い. しかし，使用する画像によっては，取得できる直線エッジが極端に短い場合がある．このような短い直線エ ッジは傾きの誤差が大きいため, これを延長して算出した仮想マーカ点の位置が大きな誤差を持つことが想定さ れる.また, 軌道上から送られる画像では, 伝送の状態によって一部のフレームに, 図 10 に示すようなちらつき が発生する場合がある．このようなちらつきは，エッジ抽出の妨げとなり，抽出された仮想マーカ点が誤差を持 つ要因となる.

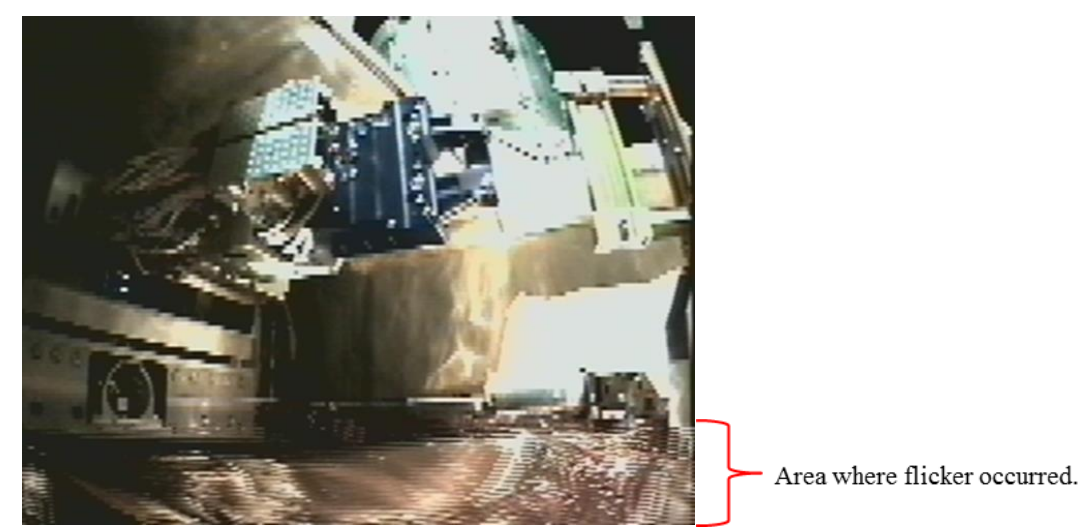

Fig. 10 With a few frames, flicker may occur. Flicker disturbs the edge extraction by image processing and the position of the virtual marker points is moved by the wrong edge.

ロボット本体の位置・姿勢を精度よく計測するため, 位置誤差が大きい仮想マーカ点は, 位置・姿勢算出のた めのデータから除外することとした。画像から抽出した仮想マーカ点の位置を評価するためには, リファレンス となる仮想マーカ点の位置が必要である. リファレンスとなる仮想マーカ点位置は, カルマンフィルタによるロ ボット本体の位置・姿勢の推定值を基に算出することとした.

カルマンフィルタは，画像処理における移動物体の追跡等に従来から使用されている．カルマンフィルタを使 用する場合，モデルが必要となるが，移動体の計測において正確なモデルを構築することは難しい．このため， 移動体は, 微小時間において, 等速運動を行なっていると仮定してモデル構築を行う手法が用いられる(梶川他, 1994).

REX-J におけるロボット本体の移動の場合, テザーリールの最大巻き取り速度は, ノミナル時において $10 \mathrm{~mm} / \mathrm{sec}$ (宇宙航空研究開発機構, 2011)である. また, 今回の計測用に取得した画像のフレームレートは, 約 $15 \mathrm{fps}$ である.このことから，フレーム間におけるロボット本体の移動量は最大でも約 $0.7 \mathrm{~mm}$ であり，これは後述 $(3.5$ 節)の分解能と比較しても十分小さい值である. よって, ロボット本体の移動速度に対する画像取得の間隔は微小 であると言える，このことから，画像取得から次のフレームの画像を取得するまでの間において，ロボット本体 は等速運動を行なっていると仮定し, 状態空間モデルを構築した. 以下にモデルを示す. 式(1)は, 位置(もしくは 角度) $x$ およ゙速度(もしくは角速度) $\dot{x}$ を成分とする状態べクトルである. 式(2)は, 時刻 $t+1$ の時の状態である. ここでAは，式(3)に示す遷移行列である. また， $v_{(t)}$ は，システム誤差である. 式(4)は, 時刻 $t+1$ の時のシステ ムからの観測量である。ここでCは，式(5)に示寸観測行列である. また， $w_{(t)}$ は，観測誤差である．この状態空 間モデルをロボット本体の各軸位置および各軸姿勢值の算出結果対して適用し，カルマンフィルタによってロボ ット本体の位置・姿勢推定值を算出した。 


$$
\begin{aligned}
& x_{t}=\left[\begin{array}{l}
x \\
\dot{x}
\end{array}\right] \\
& x_{(t+1)}=A x_{(t)}+v_{(t)} \\
& A=\left[\begin{array}{cc}
1 & \Delta t \\
0 & 1
\end{array}\right] \\
& y_{(t+1)}=C x_{(t)}+w_{(t)} \\
& C=\left[\begin{array}{ll}
1 & 0
\end{array}\right]
\end{aligned}
$$

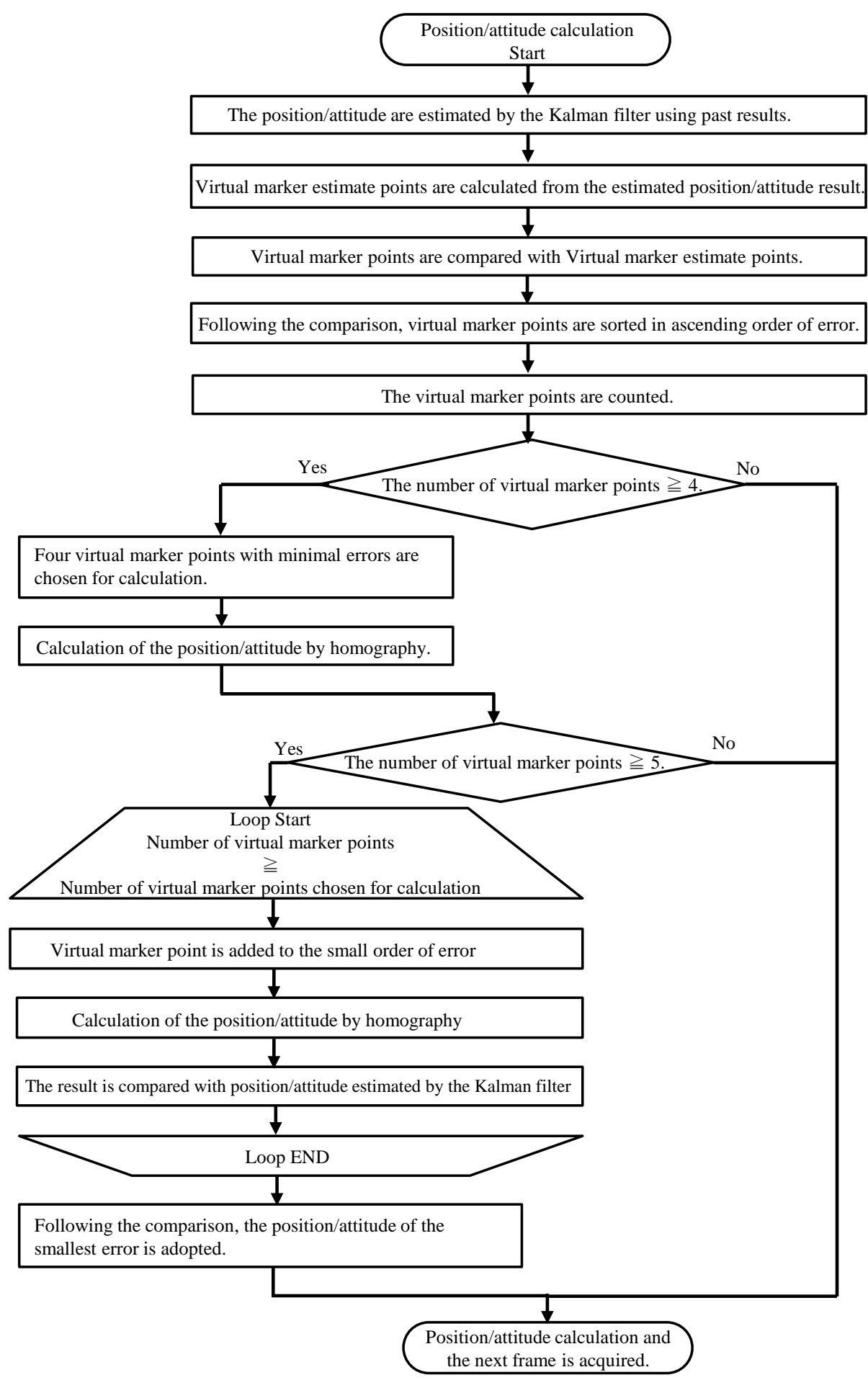

Fig. 11 Algorithm to calculate robot position/attitude. The virtual marker points used for calculation are chosen based on the estimated Kalman filter result. 
図 11 に，画像から得た特徵点を基にしたロボット本体位置・姿勢算出のアルゴリズム概要を示す．まず，カル マンフィルタを基に推定されたロボット本体の位置・姿勢值(以下，位置・姿勢推定值と呼ぶ. ) から，仮想マー カ点群の画像上における座標の推定位置（以下，仮想マーカ点群推定位置と呼ぶ.）を算出する. これと，エッジ から求めた仮想マーカ点群の画像における座標の位置（以下，仮想マーカ点群画像処理位置と呼ぶ. ）を比較し, 抽出された仮想マーカ点の位置誤差を算出した. 次に, 画像から抽出された仮想マーカ点を位置誤差の小さいも のから順に並べる．仮想マーカ点が 4 点の場合には，4 点すべてを利用してロボット本体の位置と姿勢值を求め る. 抽出された仮想マーカ点が 5 点以上の場合, 仮想マーカ点群推定位置に近い值を持つもの上位 4 点に対して, 誤差が小さい順に 1 点ずつ仮想マーカ点を加えながらロボット本体の位置と姿勢を算出する. こうして得られた 位置・姿勢の算出結果とカルマンフィルタによる位置・姿勢推定值と比較し, 位置・姿勢推定值に最も近い結果 が得られる組み合わせの仮想マーカ点群を求める．このように，不適切な仮想マーカ点を取り除くことで，不完 全なエッジからでもロバストにロボット本体の位置・姿勢值を算出することが可能となった.

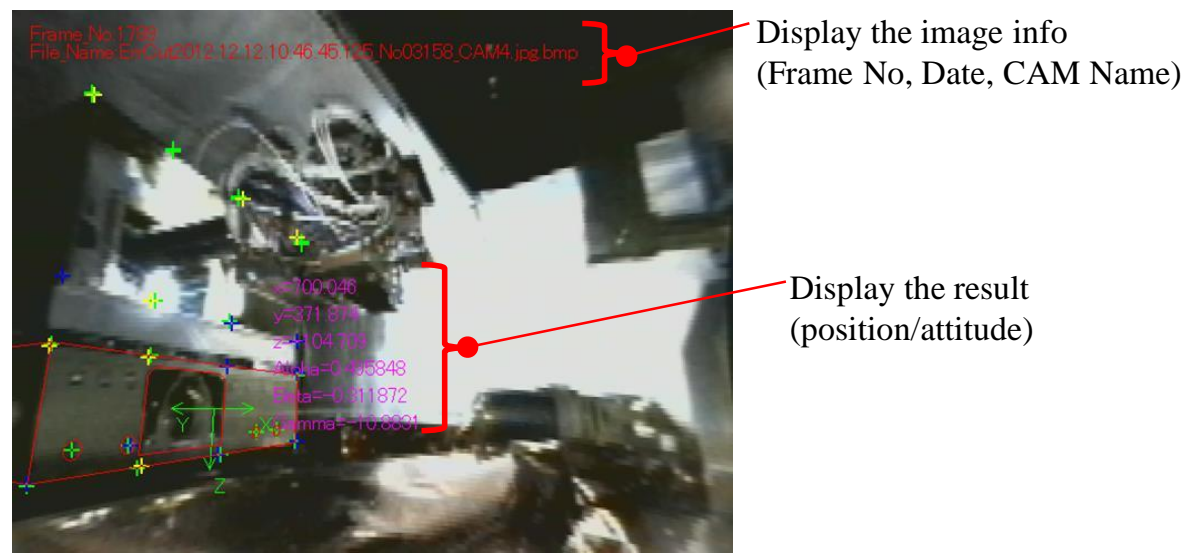

Fig. 12 Image-processing result of the robot position/attitude. Green crosses are estimated virtual marker points, while yellow crosses are virtual marker points obtained from the edges of the image and blue crosses are virtual marker points used to calculate the robot position/attitude. Blue crosses are chosen from yellow crosses. The red line show the computer graphics of the lower robot body, which are projected based on the image-processing result and using virtual marker points. When the computer graphics are aligned with the image, the image-processing result is almost right.

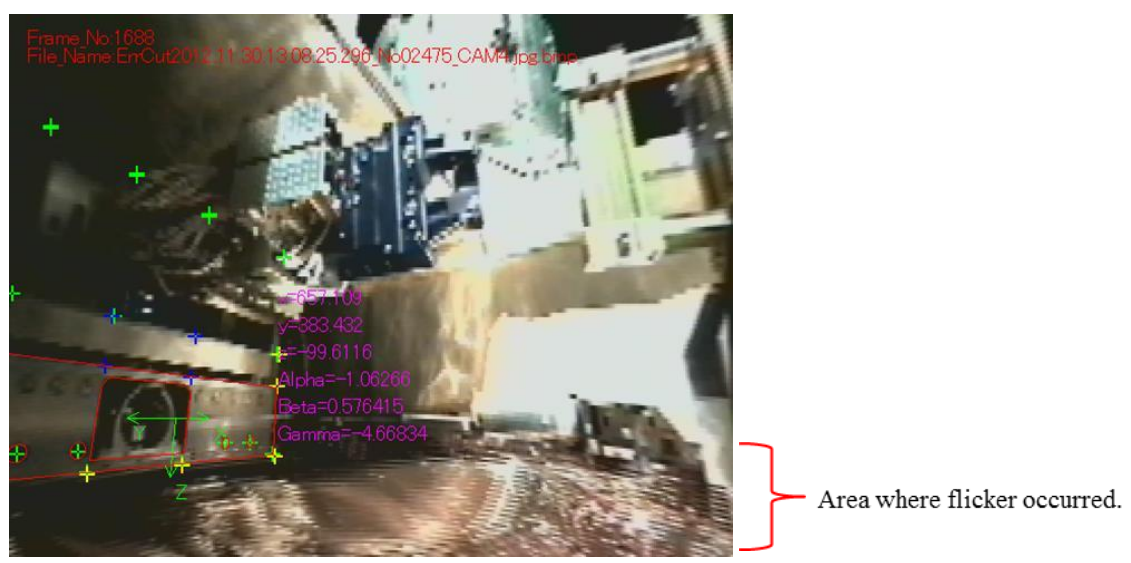

Fig. 13 Image-processing result of the image subject to flicker. Virtual marker points affected by flicker are not used to calculate the robot position/attitude.

図 12 に不適切と判定された仮想マーカ点を取り除いて位置・姿勢を算出した結果を示す. 画像中に緑色の十字 で表示されているのが，仮想マーカ点群推定位置である. 黄色の十字は, 画像中のエッジを基に算出された仮想 マーカ点を表し, 青色の十字は, 仮想マーカ点の位置誤差が小さく, ロボット本体位置・姿勢の算出に適してい ると判定された仮想マーカ点を表す．黄色と青色の十字が確認できることから，取得した仮想マーカ点がすべて 使用されるのではなく，一部の仮想マーカ点は不適切と判定されていることがわかる.また，赤い線で表示され ているのは，ロボット本体下段のコンピュータグラフィックモデルである. これは，仮想マーカ点群を基に算出 
したロボット本体の位置・姿勢を基に，コンピュータグラフィックモデルを画像中に投影したものであり，画像 と位置・姿勢計測結果のずれを視覚的に判断することができる．また，コンピュータグラフィックモデルの右側 には，現フレームにおける画像処理による位置・姿勢の計測值が紫色の文字によって表示される．この計測值の 評価については，3.5 節および 4 節にて詳細に述べる.

なお, 図 13 は, 画面下部にちらつきが発生した状態における画像処理結果である. この画像におけるロボット 本体下部のエッジは，ちらつきの影響により抽出結果に誤差を含む. このため, ロボット本体下部のエッジを基 に算出した仮想マーカ点(黄色の十字)は, エッジ抽出結果を基に仮想マーカ点としては算出されているものの, カルマンフィルタを基に算出した仮想マーカ点群推定位置とのずれが大きいために，ロボット本体の位置・姿勢 算出には不適と判定されている.

さらに，この画像ではロボット本体上部のエッジも照明環境の影響で視認できない状態である。こうした抽出 可能なエッジが限られ，直接交差するエッジを得ることができないような画像であっても，提案した画像処理手 法であれば，ロボット本体の位置・姿勢を算出するために十分な数の仮想マーカ点が得られている.さらに，こ の仮想マーカ点を基に算出したロボットの位置・姿勢を，コンピュータグラフィックスモデルとして画像上に投 影すると，画像上のロボット本体と良く一致していることが確認できる.

このような画像処理手法を用いることで，マーカがなく計測対象のエッジが視認しにくい画像であっても，口 バストに位置・姿勢值の算出が可能となった.

\section{$3 \cdot 5$ 画像処理による位置 · 姿勢計測精度の評価}

仮想マーカ点を用いた位置・姿勢計測精度の評価として, 地上実験および軌道上における撮影画像を用いて評 価を行なった.

地上実験では，暗幕中に設置したアルミ板を計測対象とし，マーカを用いた画像処理による位置・姿勢計測結 果と，提案した仮想マーカ点を用いた画像処理手法による位置・姿勢計測結果の比較を行なった.

ここで，マーカとして使用したのが，カメラのキャリブレーションに用いるドットパターンが印刷されたキャ リブレーションテーブルである. ドットパターンの位置は既知であるため, 画像から抽出したドット位置を基にキ ヤリブレーションテーブルの位置・姿勢の計測を行うことができる.

このキャリブレーションテーブルをアルミ板の中央に貼り付け，ドットパターンを用いてアルミ板の位置・姿 勢を計測した．一方，仮想マーカ点を用いた画像処理手法では，アルミ板のエッジとキャリブレーションテーブ ルの外枠のエッジを用いて仮想マーカ点を算出し，これを基にアルミ板の位置・姿勢を算出した.

図 14 に, 地上実験の結果を示す. 図 14a は, 画像処理による位置・姿勢算出に使用した画像である. 図 $14 \mathrm{~b}$ は, この画像を用いて, マーカによる画像処理と仮想マーカ点による画像処理の結果をそれぞれ表示したもので ある. 緑色で表示されているのがマーカによる画像処理結果であり, 青で表示されているのが仮想マーカ点によ る画像処理結果である. また, 図 $14 \mathrm{c}$ は, アルミプレートの一部を暗幕で覆い, エッジが不完全な状態を模擬し たものである.これより，エッジが暗幕で覆われている部分にも仮想マーカ点が算出できていることがわかる.

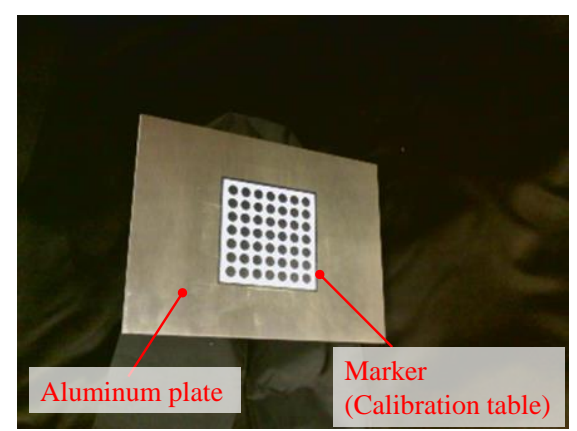

Fig. 14a Ground experiment of image-processing method.

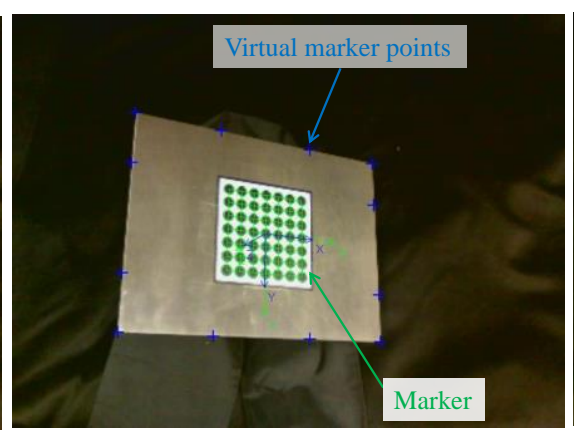

Fig. 14b Image-processing result with virtual marker points of the complete edge.

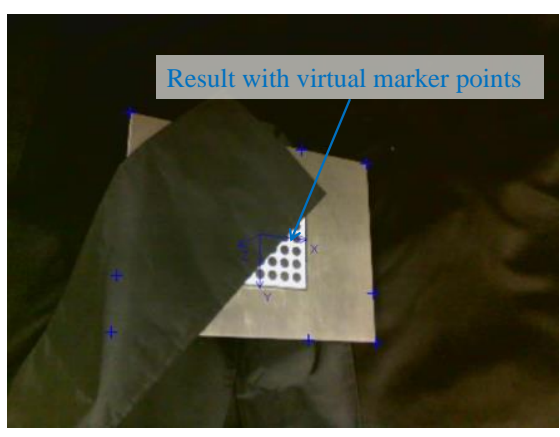

Fig. 14c Image-processing result with virtual marker points of the incomplete edge. 
表 2 に, 図 14 で示した画像を用いたアルミ板の位置・姿勢計測結果を示寸. 計測結果は，カメラ焦点位置を原 点としたカメラ座標系によって表された，アルミ板中心の位置・姿勢值である. カメラ座標系は，画面右向きを $\mathrm{X}$ 正方向，画面下向きをY 正方向，画面奥行き方向を Z 正方向と寸る. マーカを用いた画像処理手法による計測 結果と仮想マーカ点を用いた画像処理手法における計測結果を比較したところ, 画像分解能以下の誤差であるこ とが確認できた。これは，図 14c のようにエッジの一部が隠された場合でも同様であった。これより，仮想マー カ点による画像処理手法を用いることで，エッジが不完全な状態における画像であっても，精度よく位置・姿勢 值の計測が可能であることを確認できた。

Table 2 Evaluation of ground experiment of image-processing method

\begin{tabular}{c|c|c|c|c|}
\hline \hline \multirow{2}{*}{ Name } & \multirow{2}{*}{ Result with marker } & \multicolumn{2}{|c|}{ Result with virtual marker points } & \multirow{2}{*}{$\begin{array}{c}\text { Resolution } \\
\text { [mm/pixel] }\end{array}$} \\
\cline { 3 - 4 } & & Complete edge & Incomplete edge & 1.1 \\
\hline X position [mm] & -25.1 & -25.5 & -25.4 & 0.9 \\
\hline Y position [mm] & 15.7 & 15.9 & 16.0 & 1.9 \\
\hline Z position [mm] & 411.2 & 411.3 & 409.9 & - \\
\hline $\mathrm{X}$ attitude $[\mathrm{deg}]$ & -17.4 & -17.2 & -18.0 & - \\
\hline Y attitude $[\mathrm{deg}]$ & -28.2 & -28.5 & -28.6 & - \\
\hline $\mathrm{Z}$ attitude $[\mathrm{deg}]$ & -0.4 & -0.3 & -0.9 & \\
\hline
\end{tabular}

一方，軌道上における撮影画像を用いた仮想マーカ点による画像処理手法の評価では，ロボット本体位置・姿 勢が既知の状態において撮影された画像を利用した。ロボット本体位置・姿勢が既知である状態は，打ち上げ時 の振動に耐えるためのロンチロックと呼ばれる機構にて, ロボット本体が固定された状態である. 図 15aにロン チロックによってロボット本体が固定された状態の画像を示寸，ロボット本体下段の左右に見えるのが，ロンチ ロックである．画像では見えないが，ロボット本体の背面側にも板があり，ロボット本体は，板とロンチロック で挟まれるように固定されている，固定されたロボット本体の位置・姿勢值は，設計值から知ることができるた め, 画像処理による計測結果と比較が可能である，この画像は，エッジの多くがロンチロックによって隠されて いる状態であるため，画像処理に適しているとは言えないが，エッジが取得しにくい画像の一例として，画像処 理アルゴリズムの評価に使用した.

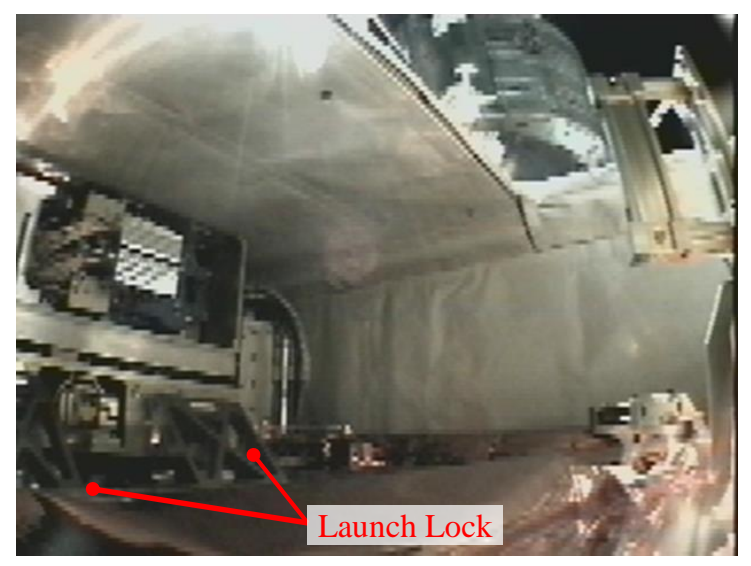

Fig. 15a Image of robot held by Launch Lock.

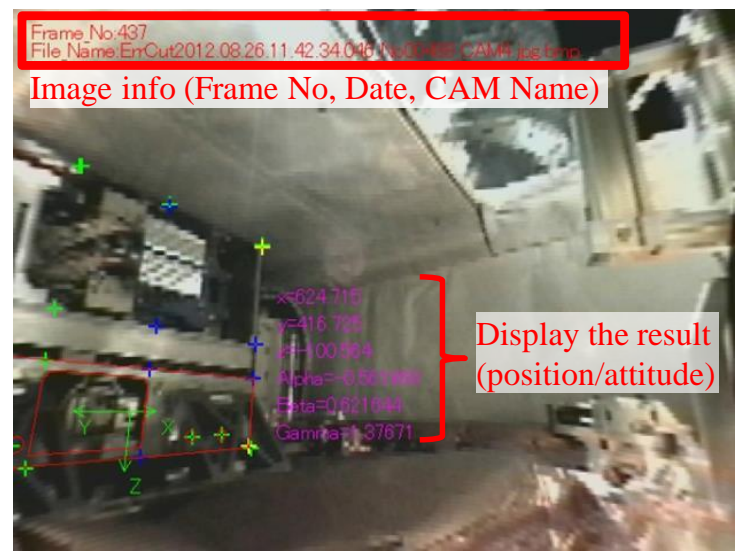

Fig. 15b Image-processing result of robot held by Launch Lock.

図 $15 \mathrm{~b}$ がロンチロック固定状態における画像処理結果である.これより，特徴形状となるエッジの多くが隠さ れていても，画像処理によってロボット本体の位置・姿勢計測が可能であることを確認できた．また，表 3 に画

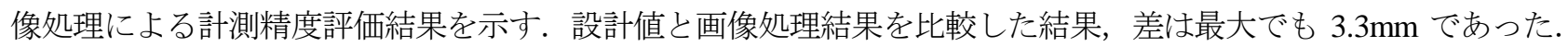
これは，画像における分解能よりも小さい值であり，サブピクセルレベルの精度でロボット本体の位置・姿勢を 
計測できることを確認した。 よって，提案した画像処理手法を用いた計測としては，カメラの性能(解像度)に対 して十分な精度が得られていると言える.

また，REX-J ミッションにおいては，サブピクセルレベルである数 $\mathrm{mm}$ 程度の誤差で位置・姿勢の計測ができ ていれば，ロボットがフックの取付け・取り外し等の作業を行うには十分な精度であると言える.

なお，画像を用いたロボット本体の位置・姿勢計測における分解能は，ロボット本体の位置・姿勢により変化 するため，一意に決定することはできない，よって，分解能の目安を知るため，ロボット本体がロンチロックに よる固定状態にある時のロボット座標系原点位置から，ロボット本体が各軸方向に一定距離 $(\mathrm{mm})$ 動くことを想定 した. この時のロボット座標系原点の画像上における移動距離(pixel)を算出寸る. これらの移動距離を基に算出 した分解能 $(\mathrm{mm} / \mathrm{pixel})$ を, 分解能の標準值とした. 本論文では, 分解能とは, 表 3 に示した分解能の標準值を指す こととする.

Table 3 Evaluation of image processing precision

\begin{tabular}{c|c|c|c|c}
\hline \multirow{2}{*}{ Name } & \multirow{2}{*}{$\begin{array}{c}\text { Designed value } \\
\text { (CAD Model) }\end{array}$} & \multicolumn{3}{|c}{ Image processing result } \\
\cline { 3 - 5 } & & Average & $\begin{array}{c}\text { Standard } \\
\text { deviation }\end{array}$ & $\begin{array}{c}\text { Resolution } \\
\text { [mm/pixel] }\end{array}$ \\
\hline X position [mm] & 630.0 & 626.7 & 2.9 & 8.1 \\
\hline Y position [mm] & 420.0 & 418.0 & 1.5 & 3.4 \\
\hline Z position [mm] & -99.0 & -100.5 & 0.5 & 3.6 \\
\hline $\mathrm{X}$ attitude [deg] & 0.0 & -0.6 & 0.3 & - \\
\hline Y attitude [deg] & 0.0 & 1.1 & 0.6 & - \\
\hline$Z$ attitude [deg] & 0.0 & 1.9 & 0.6 & - \\
\hline
\end{tabular}

\section{4. テザー移動時の位置・姿勢推定手法の評価}

ロボット本体の位置・姿勢值を，画像処理によって計測した結果(以下，画像処理計測結果と呼ぶ)とテレメト リにて得たテザー長を基に推定した結果(以下，テレメトリ推定結果と呼ぶ)とで比較し，テレメトリにて得たテ ザー長を基にした位置・姿勢推定手法の評価を行なった. テレメトリ推定結果は, リールの動作量から算出した 3 本のテザー長を入力とし， ロボット側のテザー取付け点と REX-J 実験領域におけるテザーの係留位置を基に静 安定解析によってテザーで拘束されるロボット本体の位置・姿勢值を算出した結果である. 今回, 評価に用いる テザー移動実験の例として, 表 4 に示す 2 つ移動条件を挙げる.

条件 1 は，ロボット本体が，移動起点と呼ばれるテザー移動実験の基準位置に，初めて移動した際の条件であ る. また, 条件 2 は, 条件 1 の移動から 21 回目の移動となる条件である. REX-Jにおいて, テレメトリにて得 たテザー長から推定した本体位置と移動目標位置を比較した結果, 本体移動を繰り返すことで誤差が蓄積し, 拡 大していく(山隅他, 2013)ことがわかっている. よって, 条件 2 は, 十分な回数の移動を繰り返した後のロボッ ト本体の位置を確認寸るために設定した.

Table 4 Tether-locomotion experiment was used for evaluation

\begin{tabular}{c|c|c|l}
\hline \hline No. & Date & Time(JST) & \multicolumn{1}{c}{ Note } \\
\hline 1 & December 12, 2012 & $10: 44$ & $\begin{array}{l}\text { Robot moved to the starting point of the } \\
\text { tether-locomotion experiment for the first time. }\end{array}$ \\
\hline 2 & January 17, 2013 & $14: 28$ & The 21st tether-locomotion experiment after No. 1 \\
\hline
\end{tabular}

条件 1 におけるロボット本体の位置・姿勢変化を図 16 に示寸. 点で示されているのが, 画像処理計測結果であ り, 実線で示されているのがテレメトリ推定結果である. ロボット本体位置のテレメトリ推定結果と画像処理計 
測結果を比較すると，傾向は合っているものの Y 方向位置に約 $5 \mathrm{~mm}(1.5 \mathrm{pixel})$ のオフセットが見られた. また，ロ ボット本体姿勢の画像処理計測結果では，振動しながら負方向に増加している様子が見られたが，テレメトリ推 定結果では，移動中に姿勢の変化はほとんど見られなかった。

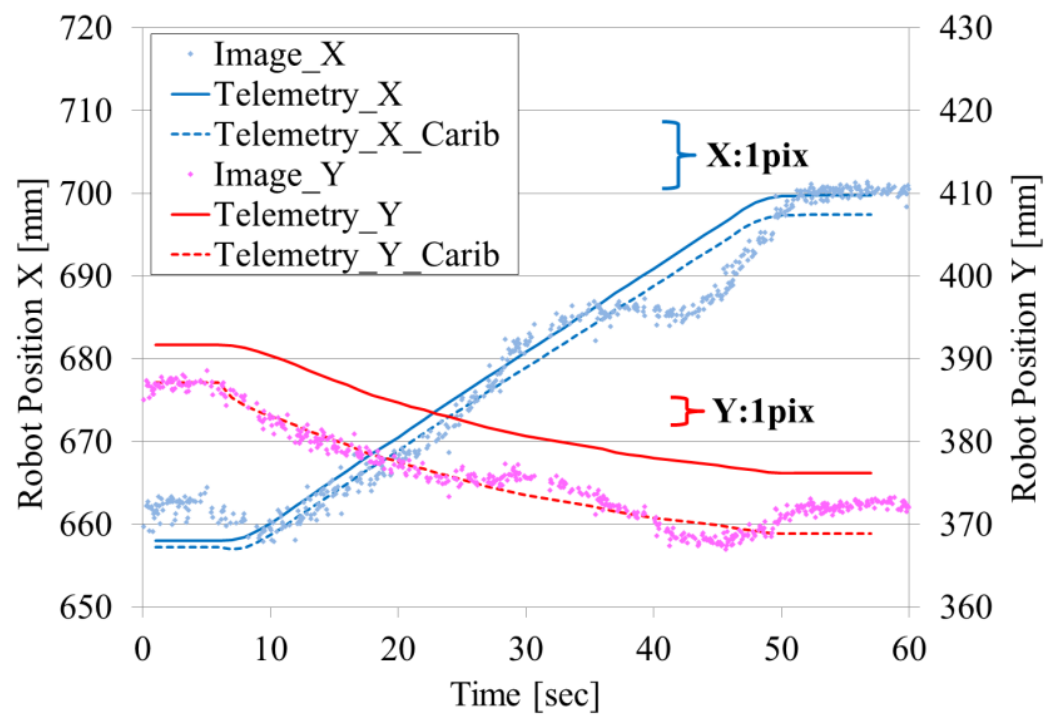

Fig. 16a Robot position on the tether-locomotion experiment No. 1. The dot shows the image-processing measurement result. The solid line is the estimated result based on the tether length of telemetry, while the dashed line is the estimated result based on the tether length of telemetry

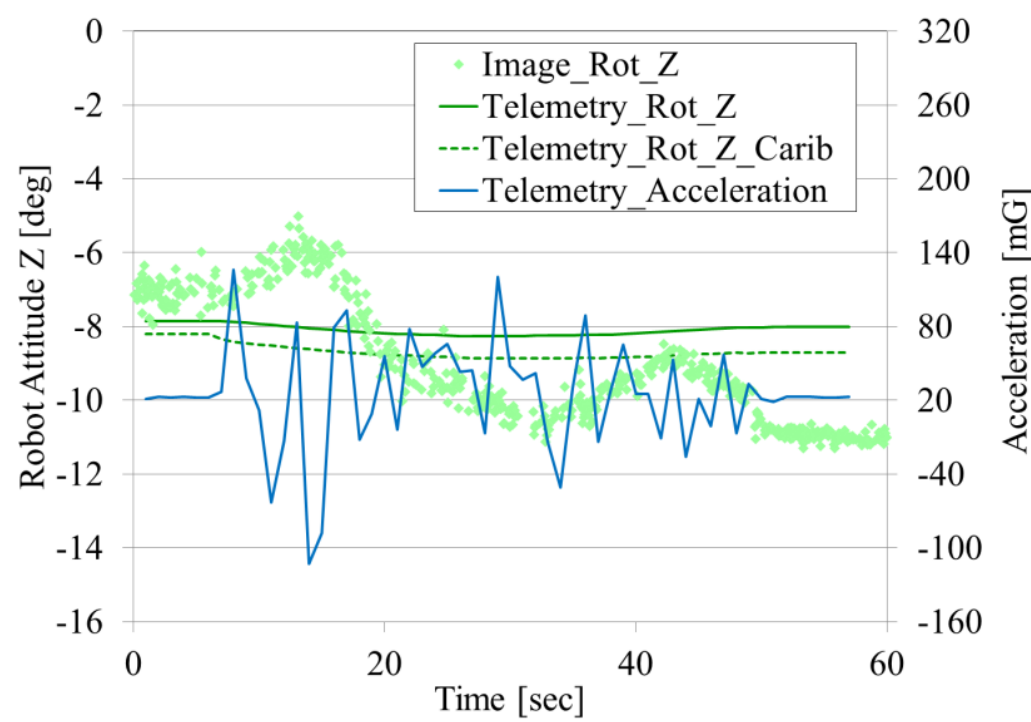

Fig. 16b Robot Attitude on tether-locomotion experiment No. 1. The green dot is the image-processing measurement result, while the green lines are estimated results based on the tether length of telemetry. The blue line is the acceleration-measurement result of the main robot body.

姿勢の画像処理計測值における振動については，ロボット本体の重心がテザーによって作られた平面外にある ことが影響していると推測できる，テザーは，ロボット本体下段に取り付けられており，この上にはSRA，手首 機構，およびロボットハンドが搭載されたロボット本体上段がある．このため，ロボット本体の重心位置は，テ ザーによって作られる平面よりも上段側に寄った位置となる。この重心のずれが，ロボット本体の移動時に振動 を発生させる原因となると考えられる. 図 16bの青い線で示しているのが，ロボット本体に取り付けられた加速 度計による計測結果である. これより, 加速度が大きく変化したタイミングで姿勢值の画像処理計測結果でも振 動が発生しているのがわかる．よって，加速度計の結果からもロボット本体が移動中に振動していることが確認 
Suzuki, Yoshii, Nakanishi, Yamazumi, Oda, Ueta, Watanabe, Kato, Hoshi and Nishida, Transactions of the JSME (in Japanese), Vol.81, No.824 (2015)

できる.これに対し，テレメトリ推定結果における姿勢值は，重心のずれ等による振動についてはモデル化して いない.このために画像処理計測結果のみで振動が観測されていると考えられる.

また，X方向位置はよく一致しているものの，Y方向位置では，テレメトリ推定結果と画像処理結果で 1pix 程 度のオフセットが見られた．姿勢值についてはオーダとしては同等であるが，移動中の姿勢変化の傾向が異なっ ていた。こうした原因の一つとして考えられるのが，テレメトリからロボット本体位置・姿勢を推定する際のテ ザー長のモデル化誤差である. テレメトリ推定值の算出に用いるテザー長は，移動前におけるテザー長の初期值 をパラメータとして設定し，これにテレメトリから得たテザー長の変化を加えたものである．移動前におけるテ ザー長の初期值は，設計情報から得たテザーの端点間の長さ，およびテザーリールの動作履歴を基に設定してい る. ただし, 初期状態において既に係留されているテザー 2 およびテザー3のテザー長については, 組立時の巻き 取り張力の影響やテザー取付け点の結び目の位置などから微小なモデル化誤差を持つことが想定され，リール動 作前の状態における正確なテザーの長さを知ることはできない. さらに，REX-J ミッションで使用しているテザ ーリール機構は，開発期間・コスト・搭載質量などの制約から，リール機構内部のテザ一緩み防止機構が省略さ れている．よって，テザーに加わる張力が低い場合，リール機構内部でテザーの緩みが発生する可能性があり， これも誤差要因となる. 一方, テレメトリにおけるテザー長は, リールの回転量から算出していることから, リ 一ル機構内部で緩みが発生した場合にはテレメトリにおけるテザ一長と, 実際に繰り出されたテザ一長が一致し ない可能性がある.よって，フックのついたテザー1 は，フック取付けの際に繰り出しと巻き取りを繰り返した 影響により誤差が蓄積していることが想定される．このようなテザー長の誤差により位置・姿勢推定結果に影響 が出ることは地上実験においても確認されている(山隅，小田，2011)，よって，テレメトリ推定結果を算出する ために使用したテザー長初期值が，誤差要因の一つであると考えられる.

一方，画像処理計測結果における位置は，3.5 節で述べたとおり，エッジの多くが隠れた状態であってもサブピ クセルレベルの精度で計測できることを確認している.

よって, 画像処理計測值を基準とし, それにテレメトリ推定值が合うよう, テザー長初期值の補正を行なった.

図 16 の破線がテザー長初期值の補正を行なった後のテレメトリ推定結果である. 補正によって, 画像処理計測 結果とテレメトリ推定結果で X・Y 方向位置がほぼ一致した。一方，テレメトリ推定結果における姿勢について は，わずかにオフセットしたものの，傾向はほぼ変わらず，テザ一長初期值の補正では画像処理結果と同等の結 果を得ることはできなかった。

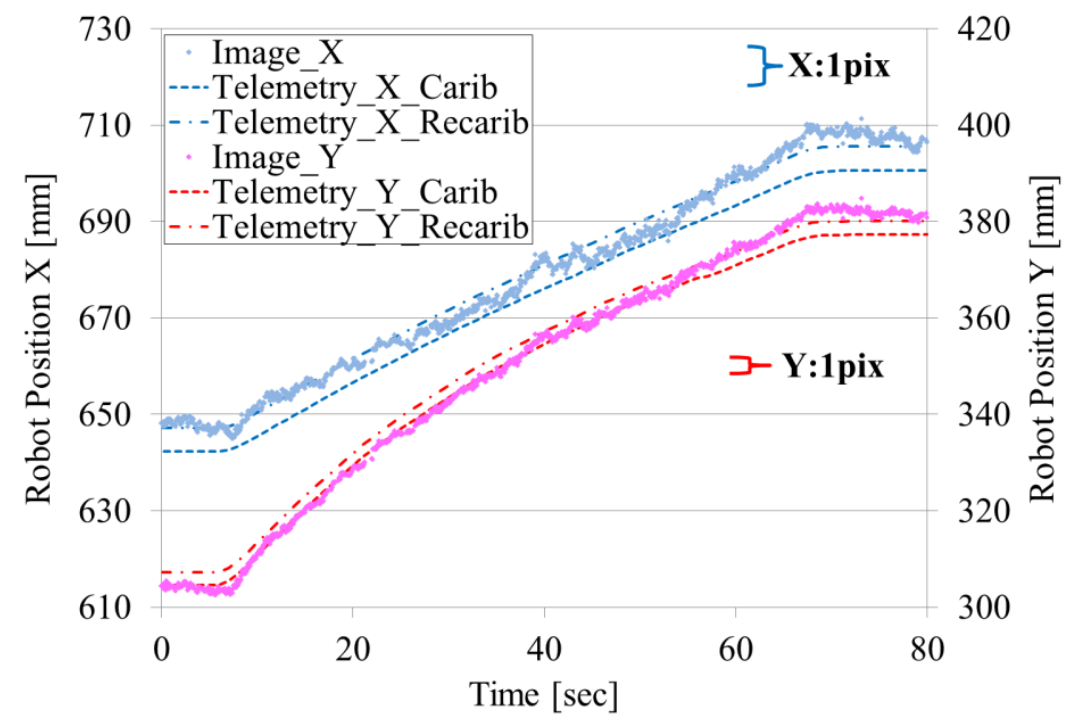

Fig. 17a Robot position on tether-locomotion experiment No. 2. The dot is the image-processing measurement result, while the dashed line is the estimated result based on the tether length of telemetry which calibrated the initial tether length. The chain line is the estimated result based on the tether length of telemetry which recalibrated the initial tether length. 
Suzuki, Yoshii, Nakanishi, Yamazumi, Oda, Ueta, Watanabe, Kato, Hoshi and Nishida, Transactions of the JSME (in Japanese), Vol.81, No.824 (2015)

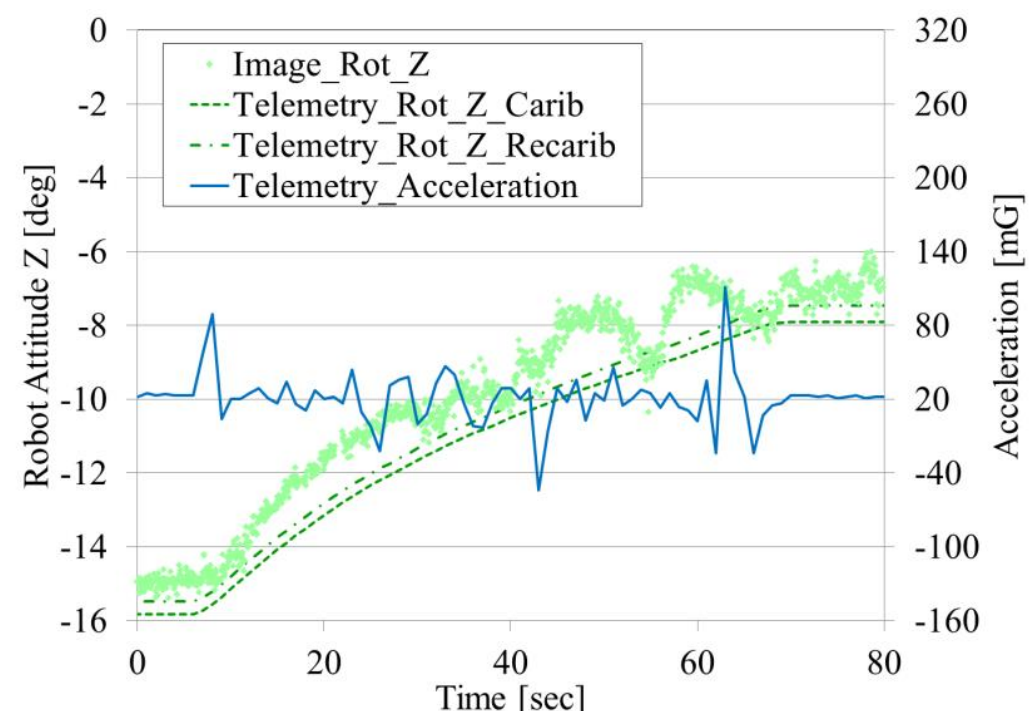

Fig. 17b Robot attitude on tether-locomotion experiment No. 2. The green dot is the image-processing measurement result, and the green lines are estimated results based on the tether length of telemetry. The blue line is the acceleration-measurement result of the main robot body.

図 17 に条件 2 におけるロボット本体位置・姿勢の変化を示寸．点で示しているのが画像処理計測結果であり， 破線で示しているのが補正後のテザー長初期值を用いたテレメトリ推定結果である. なお，条件 2 のテレメトリ 推定結果では，条件 1 の評価の際に補正したテザー長の初期值を使用してロボット本体の位置・姿勢算出を行な った. しかし，X方向位置は, 約 1pixel, Y 方向位置は約 0.5pixel のオフセットを持つことが確認できた. これは, テザー移動を繰り返すことによるテザー長の誤差が蓄積したことが原因と考え，画像処理結果に一致するよう， 条件 2 の移動前のテザー長を再度補正した. テザー長の再補正を行なったテレメトリ推定值を鎖線で示す.これ より，画像処理計測結果とテレメトリ推定結果の位置・姿勢が一致することが確認できた.

条件 1 と条件 2 におけるテザ一長初期值の補正結果を比較すると, 条件 2 ではテザ一長初期值の補正による効 果が確認できたが，条件 1 ではロボット本体位置は一致したものの，姿勢值のずれが大きくテザー長初期值の補 正による効果が確認できなかった。テザー長のテレメトリを基にしたロボット本体の位置・姿勢推定には, 静安 定解析によるモデルベースド手法を用いており，任意のロボット本体位置に対して，ロボット本体がテザーで拘 束される姿勢を数值解析によって算出している(山隅他，2013). よって，テザー長初期值の誤差による影響で位 置・姿勢值が画像処理結果とずれている場合であれば，テザー長の補正によって位置・姿勢值共に一致すると想 定される。しかし, 条件 1 では位置のみが一致し, 姿勢值にずれが見られた。一方, 条件 2 ではテザ一長の補正 により，位置・姿勢共によく一致した.

このことから，条件 1 では，別な要因がロボット本体位置・姿勢に影響を与えていた可能性が高いと言える. テザー長初期值の誤差以外にロボット本体の位置・姿勢值に影響を与える要因としては，ロボット本体に接続さ れている電源供給および通信用ケーブルの影響が考えられる. テザーの張力が低い場合，これらのケーブルの剛 性がロボット本体の位置・姿勢に影響を及ぼす可能性がある. 条件 1 と条件 2 の移動中における加速度の変化を 比較すると, 条件 1 の方が移動中の加速度変化が大きいことが確認できる. これより, 条件 1 の方が条件 2 の移 動よりも振動が発生しやすかったと考えられる．REX-J ミッションではテザー張力を精度よく計測する機能は搭 載されていないが, これらのことを考慮すると, 条件 1 における移動実験では, 条件 2 における移動実験と比較 してテザーの張力が小さく，ケーブルの剛性による影響を受けや寸かったものと推測できる.

これらの考察結果から, 条件 2 のようにテザ一長初期值の補正によって画像処理結果とテレメトリ推定結果が 一致する場合には，テザー長初期值の誤差が強く影響してテレメトリ推定結果がずれたと考えられる. 一方, 条 件 1 のようにテザー長初期值を補正してもテレメトリ推定結果における位置・姿勢值が，画像処理における計測 結果と一致しない場合では，テザー長初期值の誤差だけでなく，電源供給用および通信用のケーブル岡性が影響 していることが考えられる. 
Suzuki, Yoshii, Nakanishi, Yamazumi, Oda, Ueta, Watanabe, Kato, Hoshi and Nishida, Transactions of the JSME (in Japanese), Vol.81, No.824 (2015)

よって, テザー長からロボット本体の位置・姿勢を推定する手法は, テザー長の初期值が誤差なく計測できて いること, およびケーブル剛性等による外力の影響がない条件が重要であり，これらが既知でない条件において は, 得られる位置・姿勢值にも誤差を含む. ただし, テザー長のテレメトリ值は, 画像データと比較してデータ 量が非常に少ないため，これを用いて位置・姿勢值を推定できることは，通信容量に制限のある宇宙ロボットに とって大きな利点である.

よって，ロボットの定常的な運用においては，テザー長を基に位置・姿勢值の推定を実施し，テザ一長に誤差 が蓄積していると想定される場合，さらにテザーに緩みにより外力の影響が疑われる場合等には，画像処理の結 果を基に位置・姿勢值の確認やテザー長の補正を行うことが望ましい，このように，テザー移動ロボットの実用 化に際しては，テザー長を基にした推定と画像処理を用いた計測を組み合わせることで，より効率的な運用が可 能になると考えられる.

\section{5. 結言}

本研究は, 有人宇宙活動支援ロボットの実証実験である REX-Jミッションにおいて, ロボット本体の位置・姿 勢の計測手法の一つとして, 画像処理を用いる方法を提案した. 宇宙環境における既存の画像処理手法では, 計 測対象に特徵的なマーカを取り付け, これを基に画像処理によって位置・姿勢の計測を実施している.このため, 照明環境の変化や他の物体の影になる等の影響によりマーカの特徵点が隠れた場合には, 計測ができなくなると いう問題があった。一方，提案した画像処理手法では，計測対象のエッジを抽出し，エッジの交点を仮想的なマ 一力点として使用する。これにより，直線エッジを複数持ち，なおかつ形状が既知である計測対象であれば適用 寸ることができる，さらに，軌道上の照明環境変化やロボット自身の動作によって，一部のエッジが取得できな い場合であっても適用可能であるという利点を持つ.この画像処理手法を, REX-J ミッションにおけるロボット 本体の位置・姿勢計測に適用し, サブピクセルレベルの計測精度を持つことを確認した. これより, 提案した画 像処理手法は，照明環境が大きく変化する軌道上環境におけるマーカを持たない計測対象にも有効であるといえ る. これらのことから, デブリ等への接近や捕獲を行うミッションに対しても, 対象の形状が既知である場合で あれば，提案した画像処理手法を応用寸ることが期待できる.

また, REX-J ミッションにおけるテザー移動機能の評価として, テレメトリのテザー長からロボット本体位置・ 姿勢を推定した結果と，提案した画像処理手法を用いたロボット本体位置・姿勢の計測結果を比較した. この結 果, テザー長を基にした位置・姿勢の推定結果は, テザー長初期值の誤差の影響および外力の影響により，画像 処理結果とずれる可能性があることがわかった．ただし，これらの誤差の影響が小さい場合には，画像処理結果 とテザー長による推定結果はよく一致し, テザー長を基にした位置・姿勢推定手法が有効であることが確認でき た.

これらのことから, テザー移動を行う宇宙ロボットの実用化に向けて, 画像処理による位置・姿勢計測手法と, テレメトリのテザー長を基にした位置・姿勢推定手法を組み合わせて運用することが重要であると言える.

\section{6. 今後の課題}

今回得られた結果は, 将来のロボットによる軌道上組み立てミッションやデブリ捕獲ミッション等にも応用可 能であると考えられる，ただし，提案の画像処理手法は，計測対象のエッジを利用することから，対象が剛であ りエッジに曲がりの無いことが前提である. このため, 弾性変形が発生する可能性のある計測対象には適用する ことができないという課題がある．また，計測対象が回転している場合等，仮想マーカ点を設定した面が完全に 見えなくなる状況においては対処することができない. よって, 仮想マーカ点を設ける面を切り替える等, これ らの状況に対処するアルゴリズムの検討が必要である.

また，今回の画像撮影条件は，カメラの初期設定であるオート設定によるものであった．これは画像全体が視 認しや寸いように撮影条件が決定されるものであり, 計測対象の視認性に合わせた撮影条件とは必ずしも一致し ない.より精度の高い計測を実現する画像を得るためには，画像上の計測対象が映っている領域の明るさを判定 し, 計測対象に合わせた撮影条件を設定する等, カメラ側の制御も必要になると考える. 
Suzuki, Yoshii, Nakanishi, Yamazumi, Oda, Ueta, Watanabe, Kato, Hoshi and Nishida, Transactions of the JSME (in Japanese), Vol.81, No.824 (2015)

今後は, これらの課題に対し，軌道上のマーカを持たない機器の運動計測手法の確立や有人宇宙活動支援ロボ ットの実用化に向けて, REX-J ミッションによって得られた成果を基にさらなる研究を進めていく予定である.

\section{謝 辞}

本研究は, 宇宙航空研究開発機構 REX-J プロジェクトの一環として行われたものであり, 貴重な軌道上のデ 一タを使用させていただきました，本研究に際し，多大なるご指導を賜りました関係各位に心より御礼申し上げ ます。

\section{文献}

Canny, J., A computational approach to edge detection, IEEE Trans. on Pattern Analysis and Machine Intelligence, Vol.PAMI-8, No.6 (1986), pp.679-698.

宇宙航空研究開発機構, EVA 支援ロボット実証実験(REX-J)ミッションプレスキット(online), available from <http://robotics.jaxa.jp/rexj/pdf/20111209_REXJ_press.pdf>, (参照日 2014 年 5 月 27 日).

梶川伸哉, 大場光太郎, 石原正, 猪岡光, 単眼による三次元移動体の実時間計測法, 日本機械学会論文集 $\mathrm{C}$ 編, Vol.60, No.577 (1994), pp.3157-3163.

上村平八郎, 西田信一郎, 実用カラーマーカの製作と模擬軌道上環境での性能評価, 第 49 回宇宙科学技術連合講 演会講演集 (2005), pp.759-764.

加藤博一, Billinghurst, M. 浅野浩一, 橘啓八郎, マーカー追跡に基づく拡張現実感システムとそのキャリブレーシ ヨン, 日本バーチャルリアリティ学会論文誌, Vol.4, No.4 (1999), pp.607-616.

久保田伸幸, 榎本雅幸, 河本聡美, 仁田工美, 中西洋喜, デブリ捕獲用把持システムの概念検討, 第 56 回宇宙科学 技術連合講演会講演集 (2012), JSASS-2012-4076.

劉賀, 長谷博行, ホモグラフィ分解法による三次元運動パラメータの推定, 画像ラボ, Vol.23, No.6 (2012), pp.6876.

益子裕克, 天野萌, 鵜山尚大, 鳴海智博, 木村真一, 吉井正広, 鈴木悟史, 加藤裕基, 渡邊恵佑, 上田敦史, 西田信 一郎, 中西洋喜, 小田光茂, REX-J における軌道上自律画像誘導に向けた画像取得に関する基礎実験, 第 57 回 宇宙科学技術連合講演会講演集 (2013), JSASS-2013-4212.

増村茂樹, 画像処理システムにおけるライティング技術とその展望, 映像情報インダストリアル, Vol.34, No.1 (2002), pp.29-36.

小田光茂, 稲場典康, 宇宙ロボット/ランデブ・ドッキング用視覚センサ, コンピュータビジョンとイメージメデ イア, Vol.2002, No.102 (2002), pp.39-44.

Oda, M., Yoshii, M., Nakanishi, H., Kato, H., Ueta, A., Suzuki, S. and Yamazumi, M., Development of an astronaut support robot and its precursor REX-J, to be tested on the international space station, International Symposium on Artificial Intelligence, Robotics and Automation in Space (i-SAIRAS) (2012), $1 \mathrm{~d}$.

鈴木悟史, 中村俊之, 吉井正広, 中島正勝, 中西洋喜, 本田瑛彦, 小田光茂, 高精度画像処理アルゴリズムによる 高精度画像処理アルゴリズムによる「いぶき」太陽電池パネ ル挙動計測，日本機械学会論文集 C 編，Vol.79, No.807 (2013a), pp.4233-4248.

鈴木悟史, 吉井正広, 山隅允裕, 中西洋喜, 小田光茂, 上田敦史, 渡邊恵佑, 加藤裕基, 西田信一郎, REX-J ロボッ 卜位置・姿勢の計測のための画像処理方法, 第 57 回宇宙科学技術連合講演会講演集 (2013b)，JSASS-20134214.

山隅允裕, 中西洋喜, 小田光茂, 西田信一郎, 加藤裕基, 渡邊恵佑, 上田敦史, 吉井正広, 鈴木悟史, REX-J におけ るテザーを用いた宇宙ロボットの移動実験, 第 57 回宇宙科学技術連合講演会講演集 (2013)，JSASS-20134210.

山隅允裕, 小田光茂, 宇宙ロボットのテザーをもちいた移動手法における位置同定に関して, 第 55 回宇宙科学技 術連合講演会講演集 (2011), JSASS-2011-4158.

\section{References}

Canny, J., A computational approach to edge detection, IEEE Trans. on Pattern Analysis and Machine Intelligence, Vol.PAMI-8, No.6 (1986), pp.679-698. 
Japan Aerospace Exploration Agency, EVA support robot proving experiment (REX-J) mission press kit (online) available from < http://robotics.jaxa.jp/rexj/pdf/20111209_REXJ_press.pdf>, (accessed on 27 May, 2014) (in Japanese).

Kajikawa, S., Ohba, K., Ishihara, T. and Inooka, H., Real-time measurement of moving object by single camera, Transactions of the Japan Society of Mechanical Engineers, Series C, Vol.60, No.577 (1994), pp.3157-3163 (in Japanese).

Kamimura, H. and Nishida, S., Development of practical color marker and its performance evaluation under pseudo-orbital environment, Proceedings of the 49th Space Sciences and Technology Conference (2005), pp.759-764 (in Japanese).

Kato, H., Billinghurst, M., Asano, K. and Tachibana, K., An augmented reality system and its calibration based on marker tracking, Transactions of the Virtual Reality Society of Japan, Vol.4, No.4 (1999), pp.607-616 (in Japanese).

Kubota, N., Enomoto, M., Kawamoto, S., Nitta, K. and Nakanishi, H., Conceptual study of mechanical and sensing system for debris capturing, Proceedings of the 56th Space Sciences and Technology Conference (2012), JSASS-2012-4076 (in Japanese).

Liu, H. and Hase, H., 3D motion parameter estimation by homography decomposition (Homogurafui bunkaihou ni yoru sanjigen undou parameta no suitei), Gazo Labo, Vol.23, No.6 (2012), pp.68-76 (in Japanese).

Mashiko, H., Amano, M., Uyama, N., Narumi, T., Kimura, S., Yoshii, M., Suzuki, S., Kato, H., Watanabe, K., Ueta, A., Nishida, S., Nakanishi, H. and Oda, M., Image acquisition experiments for on-orbit visual navigation on REX-J, Proceedings of the 57th Space Sciences and Technology Conference (2013), JSASS-2013-4212 (in Japanese).

Masumura, S., The lighting technology in the image processing system and the prospects (Gazousyori shisutemu ni okeru raiting gijutu to sono tenbou), Eizojoho Industrial, Vol.34, No.1 (2002), pp.29-36 (in Japanese).

Oda, M. and Inaba, N., Vision sensors for space rendezvous docking and manipulation, Computer Vision and Image Media, Vol.2002, No.102 (2002), pp.39-44 (in Japanese).

Oda, M., Yoshii, M., Nakanishi, H., Kato, H., Ueta, A., Suzuki, S. and Yamazumi, M., Development of an astronaut support robot and its precursor REX-J, to be tested on the international space station, International Symposium on Artificial Intelligence, Robotics and Automation in Space (i-SAIRAS) (2012), 1d.

Suzuki, S., Nakamura, T., Yoshii, M., Nakajima, M., Nakanishi, H., Honda, A. and Oda, M., Measurement of the "IBUKI" solar array panel's behavior using high precision image processing, Transactions of the Japan Society of Mechanical Engineers, Series C, Vol.79, No.807 (2013a), pp.4233-4248 (in Japanese).

Suzuki, S., Yoshii, M., Yamazumi, M., Nakanishi, H., Oda, M., Ueta, A., Watanabe, K., Kato, H. and Nishida, S., Image processing method for measurement of REX-J robot's position and attitude, Proceedings of the 57th Space Sciences and Technology Conference (2013b), JSASS-2013-4214 (in Japanese).

Yamazumi, M., Nakanishi, H., Oda, M., Nisida, S., Kato, H., Watanabe, K., Ueta, A., Yoshii, M. and Suzuki, S., Space robot locomotion using tethers in the robot experiment on JEM (REX-J), Proceedings of the 57th Space Sciences and Technology Conference (2013), JSASS-2013-4210 (in Japanese).

Yamazumi, M. and Oda, M., Tether based locomotion for space robot - Position determination methods -, Proceedings of the 55th Space Sciences and Technology Conference (2011), JSASS-2011-4158 (in Japanese). 